\title{
Dynamic Role of Renewable Eenrgy to Strengthen Energy Security and Energy Poverty Reduction: Mediating Role of Low Carbon Finance
}

\section{Dinh van Tien}

Ha Noi University of Business and Technology (HUBT) Vinh Tuy Hai Ba Trung Ha Noi

Thai Van Ha ( $\nabla$ vanha280182@gmail.com )

$\mathrm{Ha}$ Nao university of business and Technology Vinh Tuy Hai Ba Trung Ha Noi

Tran Duc Thuan

Dong Nai University of Technology

Thai Thi Kim Oanh

Economics Department Vinh University

Nguyen Phan Thu Hang

Saigon University Vietnam

Pham Thi Lan Phuong

College of Agricultural Mechanics Vinh Phuc Viet Nam

\section{Research Article}

Keywords: Renewables, Africa, Energy security, Pooled effect analysis,Energy Access, Energy Supply

Posted Date: February 9th, 2021

DOl: https://doi.org/10.21203/rs.3.rs-160306/v1

License: (9) (i) This work is licensed under a Creative Commons Attribution 4.0 International License. Read Full License 
1 Dynamic Role of Renewable Eenrgy to Strengthen Energy Security and Energy

2 Poverty Reduction: Mediating Role of Low Carbon Finance

3

4

5

6

7

8

9
1

Dinh van Tien

Ha Noi University of Business and Technology (HUBT), Vinh Tuy, Hai Ba Trung, Ha Noi

Email: dvtien.napa@yahoo.com

2

Thai Van Ha

Ha Noi University of Business and Technology (HUBT), Vinh Tuy, Hai Ba Trung, Ha Noi, Email: vanha280182@gmail.com

3

Tran Duc Thuan

Dong Nai Technology University (DNTU), Bien Hoa City, Vietnam

Email: tranducthuan@dntu.edu.vn

\section{Thai Thi Kim Oanh}

Economics Department, Vinh University (VU), Vinh City, Vietnam

Email: thaithikimoanhkt@gmail.com

5

Nguyen Phan Thu Hang

Saigon University, Vietnam

Email:npthuhang@yahoo.com 


\section{Pham Thi Lan Phuong}

29
College of Agricultural Mechanics (CAM), Vinh Phuc, Vietnam

Email: phuongcknn@cam.edu.vn

*Corresponding Author : Thai Van Ha (vanha280182@gmail.com)

\section{Introduction}

Renewables allow African countries to transition to cleaner consumption. The costs of renewables

6 have been falling since 2009, making them cost-competitive to fossil fuels source. Yet Africa

installs about $2 \%$ of the global capacity of Renewable energy capacity(RE) in about a decade.

Despite the abundant theoretical and economic potential of renewables in the continent. Thus, this 
59 study seeks to delve into the determinants of scaling up RE resources in Africa's five most 60 populous countries, estimating energy access, regulatory Quality in a country, effective 61 compliance in a country, Carbon dioxide emissions levels, Access to clean fuels and technologies 62 for cooking, energy imports, electricity generation from fossil fuels sources, GDP growth and 63 Renewable energy consumption (\% of total final energy consumption) as the dependent Variable.

64 Cleaner production (C.P.) aims to boost production efficiency and eliminate or reduce waste from 65 being produced rather than the firefighting approach or treat the waste when they occur. C.P. 66 gained traction towards the end of the 1990s, where good environmental results and economic 67 gains were attained through innovative industrial projects. Before then, national Cleaner 68 production centers (NCPLCs) were set up by UNIDO and the UNEP in 1994 to boost cleaner 69 productions in emerging and transitioning economics. Creating awareness and making 70 governments and businesses implement policies and adopt technologies to reduce waste and 71 pollutions(Sakr \& Abo Sena, 2017). Climate change has become more pronounced and urgent in 72 our dispensation. Governments institute green industries by formulating economic policy 73 instruments to scale up these industries to reduce waste and environmental pollution. For instance, 74 in South Africa, one of the focus areas of the NCPC-SA is renewables and Nuclear energy, which 75 are carbon-free energy sources and cleaner. South Africa plans to enhance existing industries' 76 production capacities, create green jobs in the economy by 2020 , and fight climate change(NCPCs, 77 2013).All these lofy goals can be attained through the right investmet. Eighteen Sub Saharan 78 Africa countries (SSA) have attracted about \$18 Million in RES investment in 2018(Bloomberg 79 NEF, 2020).

80 Besides, over 2.8 billion people worldwide still cook with solid Biomass, and nearly 800 million 81 people don't have access to electricity(Cooking with Electricity, 2020.).This means around a 
82 billion people have access to electricity and still cook with Biomass ( Cooking with Electricity,

83 2020). It is is even more important for developing countries, where they rely more on fossil fuels

84 to generate electricity. Africa generates more than $81 \%$ of its electricity from thermal sources,

85 emitting carbon dioxide, and costly, that is not sustainable(Alemzero et al., 2020). As the world

86 strives to contain the rise of global temperature beyond the1.5 degree Celsius levels, renewables

87 sources are seen as the mainstays to achieving this aim and at the same time attaining energy

88 security. Renewable energy is directly linked to energy security. Thus, renewables sources supply

89 energy clean to the population, reduce or eliminate Carbon dioxide emissions levels and ensure

90 energy security. Energy security has been defined as , power should be available at all prices, and

91 there is no danger of its supply (Narula, 2019) and (Alemzero et al., 2020). Energy security became

92 a global concern during the 1970 oil crisis that saw oil prices sky rocked and made nations started

93 looking for alternative cheaper sources of energy to meet their energy needs. This brought about

94 the formation of oil exporting countries (OPEC) as a cartel to promote oil producing countries'

95 economic interest. Energy secuirty has even gained traction recently, given the Paris Agreement's

96 importance to limit global emissions levels by 1.5 degrees Celsius. The concern now is not oil

97 price volatility but how to scale up renewable technologies such as Wind, Solar, Biofuels,

98 Geothermal, hydropower, etc., to sustainably meet the Paris Accord. Even though African

99 countries have not been insulated from defined energy crises since the 1970s, the only way for

100 African countries to secure their energy future is to embrace renewables energy production, which

101 is economically compelling for them to integrate into their grids. Thus, this study seeks to see how

102 the five countries selected from the various sub-regions can secure their energy futures by

103 consuming renewables generating technologies. These countries are Nigeria from West Africa,

104 South Africa from Southern Africa, Egypt from Northern, Ethiopia from East Africa, and DR. 
105 Congo from Central Africa. African countries are still in the lock-in state of diversifying their energy mix, consuming an overwhelming $81 \%$ of their energy from fossil fuel sources(Alemzero

107 et al., 2020).

108 Moroso, Africa is a continent on the move with rapid population growth, urbanizing at $4 \%$ a 109 year(RES4,2020) and a growing gross domestic product growth of averagely $3 \%$ till 2030(Alemzero et al., 2020). Efforts have been made across the continent to boot renewables production with the formation of the African renewable energy initiative(AREI) in 2015, which

112 seeks to achieve new and additional renewable capacity by 2020 and 300GW by 2030 Alemzero 113 et al., 2020). Furthermore, the Clean Energy Corridor (ACEC) formation is supported by the 114 A.U.'s Agenda 63 program to scale up renewable capacity in the continent(IRENA, 2019). The 115 pooled ordinary least squared clustered method(OLS) was used in analysing the data from a panel 116 of 5 countries from 2001-2019.This paper contributes to the policy debate on renewables 117 deployment in Africa. Firstly, it gives insights on the important factors to deploying renewbles in 118 Africa. Second, it has introduced new varibles on the deteminants such as quality of the regulatory 119 enviroment and the effectiveness of compliance to estimate, using the pooled ordinary least 120 squared method.Most papers on this topic on Africa don't consider these factors.Finally, it adds to 121 a growing knowldge of literature on this field.

122 The rest of the paper is organized as follows; Chapter two does a deep analysis of the study's 123 relevant literature. Chapter three is the methodology, while Chapter four covers the results and 124 discussion, and chapter five wraps up with the conclusion.

\section{Literature Review}

127 Table 1 shows the macroeconomic indicators of the study countries. The Gini coefficient explains 128 the income distribution of a population. How uneven income in a population is distributed. 
129 Economic growth continues to be robust among these countries, which make up the chunk of the 130 population in the African countries. The Democratic Republic of Congo has the second-highest 131 population growth rate among the study countries and certainly one of the highest on the continent. 132 The country has more than 84 million people, with a 72872 billion gross domestic product and a 133 per capita income of $\$ 867$.The average real GDP growth rate is 5.9 percent from 2010-2020, on 134 a steady growth path. However, the pandemic has likely distorted this steady growth pathway. The 135 country's real GDP growth was projected to grow by $3.9 \%$ downward in 2020 and $3.4 \%$ in 136 2021(AfDB, 2020). But for the pandemic, these projections would be revised downwards since 137 the demand has slowed from China for its mineral resources. Copper and cobalt have all seen a 138 significant drop in prices. DRC's economy relies heavily on these raw materials. The extractive 139 sector forms the nucleus of the economy of the country.

140 The GDP growth is expected to be reduced by 6.2 and 8.1 points, giving rise to a budget and 141 current account widening deficit coupled with inflation doubling against what was initially 142 projected(AfDB, 2020). The real GDP growth rate is forecasted to contract by $2.3 \%$ in 2020 , as 143 the pandemic continues to the first half of 2020 and will worsen by $4.2 \%$ by the worst-case scenario 144 if the pandemic continues to December(AfDB, 2020). The country's economy lacks diversity and 145 relies mostly on the primary sector, dominated by mining. The Gini coefficient for DRC is $42.1 \%$, 146 which is very high for the country. This explains the uneven distribution of income in the country. 147 The wealth in the country is not equally distributed among the population. That is almost half of 148 the people of varying income distribution in the country. The higher the Gini coefficient, the 149 inconsistent the income distribution.

150 Ethiopia is one of the countries in East Africa with the fastest economic growth rate. Ethiopia has 151 the highest population growth rate of $8.2 \%$ of about 108 million people, with GDP per capita of 
152 half of more than a thousand dollars, \$550. Ethiopia has a GDP of 220 billion dollars. Ethiopia’s

153 average real GDP growth rate since 2010 is 9.7 percent; this is quite a robust growth pathway the 154 country is heading. Ethiopia even projects to grow its GDP by $11 \%$ over the 155 decade(Selvakkumaran \& Silveira, 2018). The country relies mostly on agricultural products; it 156 gives the country about $65 \%$ of its foreign exchange, and tourism makes up 9\% of its GDP(AfDB, 157 2020). The country's real GDP rate is forecasted to decline from before the COVID-19 figure of $1587.2 \%$ to $3.6 \%$ Covid-19 level, and the worst-case scenario of 2.6\% to December(AfDB, 2020). 159 The country has a Gini Coefficient ratio of $39.1 \%$, indicating the country has uneven income 160 distribution of about $40 \%$. The wealth of the country is skewedly distributed.

161 Egypt is a more developed country relative to other countries in the study. It has a population 162 of almost 100 million people, growing at $1.9 \%$ with a GDP of more than $\$ 1$ billion people as of 163 2018. Its GDP per capita is $\$ 13,051$ as of 2018. The country has an average annual GDP per capita 164 of 3.9 percent since 2010. Egypt's Gini coefficient is $31.9 \%$, the lowest among the countries. That 165 explains the country's wealth is, to some extent, distributed equally to the rest of the study 166 countries. Egypt's economy depends solely on natural resources such as oil and gas, and so the 167 pandemic worsens its foreign exchange earnings position, with a current account balance of a 168 negative 6.1\%. Besides, Egypt undertook significant structural reforms in 2017-18. This resulted 169 in substantial improvement in the ease of doing business in the country and a robust regulatory 170 and legal framework. The energy sector equally became very sustainable and competitive, with an 171 enhanced governance system. The public power sector saw power supply outstripping demand, 172 creating a surplus(Bank African Development, 2019). These achievements could be reversed due 173 to the pandemic; real GDP is forecasted to fall $2.2 \%$ in $2020,5.6 \%$ in 2019 , and return to the 174 growth path in 2021(Bank African Development, 2019). 
If the pandemic persisted to December, the economy would reduce by $0.8 \%$, meaning Egypt will be the only country attaining a positive growth pattern in North Africa (African Development

177 Bank, 2019. The increase in the Pandemic spendings will further exacerbate the country's fiscal 178 deficit to $8.5 \%$ in 2020 in the face of lower revenues, culminating in public debt reaching $17985 \%$ (Bank African Development, 2019). Egypt's government took measures to alleviate the 180 pandemic's adverse effects on the economy and people by putting together a stimulus package 181 worth \% 6.34billion dollars, which is $1.6 \%$ of Egypt's GDP. The country reduced gas prices for 182 industry and a stimulus package of 63 million dollars (Bank African Development, 2019).

183 Nigeria has the third-highest GDP growth rate among the study countries of $2.6 \%$, with almost 184200 hundred million people. The government has a GDP per capita of $\$ 5,969$, with a total GDP of $185 \$ 1169$ billion. Its average GDP per capita for a decade starting from 2010 is $3.6 \%$. This explains 186 a significant economic growth trajectory for Nigeria for the period. Most surprisingly, its Gini 187 Coefficient $43.0 \%$ is the second worse one among the study countries surveyed in 2009. This 188 explains that $43.0 \%$ of the country's population experiences an uneven income distribution. That 189 is quite remarkable for Africa's biggest economy. It further emphasizes the point that the nation's 190 wealth is in the hands of a few people.

Nigeria is bearing the pandemic's brunt with weak economic performance as oil price volatility 192 hit the nation due to the pandemic. Oil prices fell to almost pre-COVID levels of $60 \%$ per barrel 193 at the start of the year to $30 \%$ in March. The country relies mostly on oil and gas revenue. Nigeria's 194 real GDP is forecasted to reduce around $4.4 \%$ and $7.2 \%$ due to the pandemic persisting and its 195 severity(AfDB, 2020). This will undo the significant gains choked during the consistent three years 196 of economic growth since 2016. 
Oil and gas make up $90 \%$ of Nigerian's foreign exchange earnings and more than $50 \%$ of the government's fiscal revenue(Hepburn et al., 2020)(AfDB, 2020). The government's revenue is forecasted to fall by $90 \%$ in 2020 due to lower oil demand coupled with increased spending increasing the budget deficit to about $6.7 \%$ and $7.8 \%$ in a worst-case scenario(AfDB, 2020). All this will increase the current account deficit to $5 \%$ in the country's worst-case scenarios, provided the pandemic goes beyond 2020. (AfDB, 2020)(Hepburn et al., 2020)

In the light of these economic woes, the country has come out with a stimulus package to lessen the pandemic's burden. It has set up a naira 500 billion credit facilities ( $\$ 1.4$ billion) to aid the 205 health sector, give tax relief to the populace, and encourage companies to continue to employ even amid the pandemic. (AfDB, 2020). The government has increased the number of conditional cash transfers to the households to 3.6 million and reduced the interest rate from $9 \%$ to $5 \%$ (AfDB, 2020). All these aimed at cushioning the impact of the pandemic.

South Africa is Sub Saharan Africa's second-largest economy, with a population growth of $1.2 \%$ and nearly 60 million people. Its GDP per capita is \$7,525 and GDP of789billion dollars. South Africa's average annual GDP growth since 2010 is $1.9 \%$, showing the country has been on 212 a slower growth pathway. Its Gini coefficient is the highest among the countries in the study. This shows the stark reality of the uneven distribution of wealth in South Africa. Despite its GDP per 214 capita, the income distribution is highly irregular. This does not promote social inclusion.

216 due to inefficient structural reforms in the energy sector and labor rigidity. This has had dire 217 consequences on the economy. The economy has been growing on average of $1.1 \%$ for the last 218 five years(AfDB, 2020). The country is faced with hydra-headed problems of a high unemployment rate of $30 \%$ coupled with economic contraction in the second half of 2019 as well 
220 as the COVID-19 and its resultant effects, electricity supply bottlenecks, and financially distressed

221 state-owned companies, making the growth in 2020 almost nonexistent (AfDB, 2020). The

222 economy grew by $0.2 \%$ in 2019 , the least in a decade; the GDP will contract $6.3 \%$ in 2020 and

$2237.5 \%$ in the worst-case scenario. According to the South African revenue service, the country's

224 fiscal situation has been made worse by the loss of ZAR285 billion or \$15billion, exacerbated by

225 the pandemic(AfDB, 2020), (Table.1). The COVID-19 could cause a 12\% fiscal deficit and 3.9\%

226 current account deficit of GDP AfDB, 2020). The government with its development partners, set

227 up a fund to lessen the effects of the pandemic on the populace.

228 Table 1. Macroeconomic indicators

\begin{tabular}{|c|c|c|c|c|c|c|c|}
\hline & $\begin{array}{l}\text { Population growth } \\
\text { rate }(\%)\end{array}$ & $\begin{array}{l}\text { GDP per } \\
\text { capita }(\$)\end{array}$ & $\begin{array}{l}\text { Total } \\
\text { Population( } \\
\text { Millions) }\end{array}$ & $\begin{array}{l}\text { GDP } \\
\text { (billion } \\
2018 \\
\text { USD) } \\
\end{array}$ & $\begin{array}{l}\text { Average GDP growth } \\
\text { rate } 2010-2020\end{array}$ & $\begin{array}{l}\text { Gini } \\
\text { Coefficient }\end{array}$ & \\
\hline Country & & & & & & Survey year & Value \\
\hline DRC & 3.3 & 867 & 84,005 & 72,872 & 5.9 & 2012 & 42.1 \\
\hline Ethiopia & 8.2 & 550 & 108 & 220 & 9.7 & 2015 & 39.1 \\
\hline Egypt & 1.9 & 13,051 & 99,376 & $1,296,973$ & 3.9 & 2015 & 31.8 \\
\hline Nigeria & 2.6 & 5,969 & 196 & 1169 & 3.6 & 2009 & 43 \\
\hline South & & & & & & & \\
\hline Africa & 1.2 & 7,525 & 57 & 789 & 1.9 & 2014 & 63 \\
\hline
\end{tabular}

229 Source: African Economic Outlook Supplement, 2020

\subsection{Electricity Access}

231 Table 2 gives energy access of the countries. Energy access continues to be a thorny development

232 issue on the African continent. About 565 million people have no access to electricity in Africa, 233 about $50 \%$ of Africa's population(SEforALL, 2020). In the absence of electricity, African 234 countries cannot eliminate poverty, access essential health services, and create an energy economy. 235 Table 2 shows that the DRC has an access rate as low as $19.0 \%$, and half of the urban population 236 has access to electricity. However, only a minute $1 \%$ of rural areas have electricity access. On the 237 other hand, renewable energy consumption, a percentage of total energy consumption, is relatively 238 high, at $95.8 \%$. DRC plans to double down on renewables' share on final energy consumption to 
nearly $100 \%$ in 2030 (Selvakkumaran \& Silveira, 2018). On the contrary, renewables' per capita consumption is deficient (Selvakkumaran \& Silveira, 2018). The figure is coming from hydro sources. DRC aims to have a $75 \%$ electricity access rate by 2030 , resulting in $80 \%$ electrification in urban areas and 70\% in rural areas, as against 100\% envisaged by the SDGs(Selvakkumaran \& Silveira, 2018). DRC has many hydro resources potential; especially, If the grand Inga dam is constructed, it could meet DRC's 100\% electricity demand(Selvakkumaran \& Silveira, 2018). The country's Hydro resources are estimated at 100GW; out of this number, only $2.4 \mathrm{GW}$ was tapped into (Selvakkumaran \& Silveira, 2018). Furthermore, access to clean fuels and technologies for cooking is as low as $4.02 \%$. About 68 million people still lack access to energy in DRC, of the about 84 million people. This will retard socio-economic development and exacerbate inequality in the country.

Ethiopia is another country that is less electrified among the study countries. Its urban electricity access rate is nearly $100 \%$, while the rural access rate is $32 \%$. The share of renewable energy in final consumption is $92.2 \%$. Ethiopia plans to take this to almost $100 \%$ by 2030 (Selvakkumaran \& Silveira, 2018). Ethiopia's access to clean fuels and cooking technologies is the lowest among the study countries, with a value of $3.51 \%$. The inadequate access to clean technologies explains the country uses more polluting sources for cooking. Air pollution is the most casual risk factor of untimely deaths in Ethiopia(Beyene et al., 2018). Furthermore, in Ethiopia, about 65000 premature deaths occurred due to household pollution from cooking with solid fuels and 3.1 million disability-adjusted life- years per year (Selvakkumaran \& Silveira, 2018).

Similarly, about $95 \%$ of Ethiopian households cook using polluting fuels and technologies, especially firewood, and the number is almost a hundred in the countryside(Beyene et al., 2018). The situation is even worse for rural areas since they are less electrified, but the problem is better 
262 in urban centers, with a high value of $38 \%$ biomass and $30 \%$ firewood(Beyene et al., 2018). Urban

263 centers households use about one-fourth of clean fuels and technologies, $23 \%$ use electricity for 264 cooking, and 1\% with liquefied petroleum gas(LPG)(Beyene et a,2018.) Ethiopia has about 60 265 million people without access to electricity and aims to achieve $75 \%$ electrification rate in 2030 266 through their Intended Nationally Determined Contributions(INDC) (Selvakkumaran \& Silveira, 267 2018)(SEforALL Sustainable Energy for All, 2020).

268 Egypt is the only country that has achieved a 100\% electrification rate among the study countries. 269 According to (Godinho \& Eberhard, 2019), Egypt has nearly attained universal access in 2007 and 270 got all hooked on the national grid. Egypt's government set up the Rural Electrification Authority 271 (REA) in 1971 to ensure ubiquitous excess to grid electricity(Godinho \& Eberhard, 2019). Once 272 the government's rural electrification program was achieved, the government disbanded the REA. 273 The country has universal access for urban and rural areas and has gained $97.6 \%$ access to clean 274 fuels and cooking technologies. On the other hand, the renewable energy consumption of total 275 final consumption is $5.7 \%$, which is relatively less low.

276 Supporting research done by(US EIA, 2018) Egypt is the topmost consumer of natural gas and oil 277 products in Africa, making up $22 \%$ of petroleum products and $37 \%$ of dry natural gas consumption 278 in 2016. The issue of cleaner production has become so central to Egypt as this narrative shows 279 the country is not producing and consuming clean fuels. Hence the government launched the 280 Egyptian Pollution Abatement Project(EPAP), which seeks to encourage renewables production 281 in Egypt(Hamed \& El Mahgary, 2004). The issue of pollution is a primary concern for Egypt due 282 to Egypt's importation of oil and gas to meet rising domestic consumption. As a result, the 283 government has adopted measures to meet this increasing demand, neglecting energy efficiency 284 (Sakr \& Abo Sena, 2017). The growth in fossil fuel supply has worsened the pollution rate in 
285 Egypt. The country bore the brunt of the most damage cost of air pollutions, which is $21 \%$ of its

286 GDP in the MENA region, responsible for the overall 44\% environmental costs to Egypt(Sakr \& 287 Abo Sena, 2017). According to (Sakr \& Abo Sena, 2017), if a country implements an energy 288 efficiency program that reduces per capita oil consumption by $10 \%$, it could reduce particulate 289 290 help Egypt achieve energy security and avoid pollution.

291 Nigeria has about 56.5\% access to electricity of almost 200 million people. According to (Aliyu 292 et al., 2018), Nigeria aims at a 75\% electrification rate in 2020 but still lags in achieving the target.

293 Urban Access to electricity is $81.9 \%$, and rural access is woefully $30.9 \%$. Also, renewable energy 294 consumption in final energy consumption is $86.6 \%$, and access to clean fuels and cooking 295 technologies is $4.9 \%$.In Nigeria, $91 \%$ is the total energy consumption in the housed hold, mostly 296 done using wood fuels, causing an estimated 129 million Nigerian vulnerable to diseases and 297 deaths due to pollution from cooking with unclean fuels. (Jewitt et al., 2020). Considering the 298 importance of clean cooking technologies, Clean Cooking Alliance(CCA) was formed to press 299 home the significance of creating "clean" cooking systems(CCS) other than just stoves to deal 300 with Household Air Pollution (HAP) and environmental pollution(Jewitt et al., 2020). And the 301 total number of people without access to electricity across the country are 85 million people. Given 302 this situation of Nigeria, the government plans to increase its cleaner energy technologies such as 303 Biopower by 400 MW in 2025, small scale Hydropower to 2 G.W. by 2025, Solar power, large 304 scale by $500 \mathrm{MW}$ by 2025 , Windpower by $40 \mathrm{MW}$ in 25 , CSP by $5 \mathrm{MW}$ in 2025 (Aliyu et al., 2018). 305 Furthermore, Nigeria has an estimated $14750 \mathrm{MW}$ for small and large scale hydro reserves and 306 about $3.5-7.0 \mathrm{~kW} \mathrm{~h} / \mathrm{m}^{2} /$ day Solar radiation and wind speed of $2-4 \mathrm{~m} / \mathrm{s}$ at $10 \mathrm{~m}$ height(Aliyu et al., 307 2018). 
Finally, South Africa is the most electrified country in Sub Saharan Africa, with $91.2 \%$ of the population hooked to the grid. Urban Access to electricity is $92.0 \%$, and rural access to electricity is $84.6 \%$. The percentage of renewables in final energy consumption is $17.1 \%$, and access to clean

311 fuels and technologies for cooking is 84.75\%, the second-highest after Egypt in the study countries.

312 South Africa sees renewables as a way to ensure sustainable development and promote sustainable

313 consumption of energy. The renewable independent power producer program(REIPPP) had an

314 initial plan of generating $45 \%$ for solar and $40 \%$ for Wind in the country, having all targets

315 attaining a value of $65 \%$ for all auctioning rounds, creating a local content value of $\$ 4.7$ billions

316 for all projected committed(IRENA, 2019).

317 Table 2. Macroeconomic indicators related to energy poverty

\begin{tabular}{|c|c|c|c|c|c|c|}
\hline Country & $\begin{array}{l}\text { Access to electricity }(\% \text { of } \\
\text { the population) }\end{array}$ & $\begin{array}{l}\text { Access to } \\
\text { electricity }(\% \text { of } \\
\text { urban } \\
\text { population) }\end{array}$ & $\begin{array}{l}\text { Access to } \\
\text { electricity, } \\
\text { rural (\% of } \\
\text { rural } \\
\text { population) }\end{array}$ & $\begin{array}{l}\text { Renewable } \\
\text { energy } \\
\text { consumption } \\
\text { (\% of total } \\
\text { final energy } \\
\text { consumption) }\end{array}$ & $\begin{array}{r}\text { Access to clean fuels and } \\
\text { technologies for cooking (\% of } \\
\text { the population) }\end{array}$ & $\begin{array}{l}\text { Number of people } \\
\text { without } \\
\text { electricity(Millions) }\end{array}$ \\
\hline DRC & 19 & 50.7 & 1 & 95.8 & 4.02 & 68 \\
\hline Ethiopia & 45 & 92 & 32.6 & 92.2 & 3.51 & 60 \\
\hline $\begin{array}{l}\text { Nigeria } \\
\text { South }\end{array}$ & 56.5 & 81.7 & 30.9 & 86.6 & 4.9 & 85 \\
\hline Africa & 91.2 & 92.1 & 84.6 & 17.1 & 84.75 & 5 \\
\hline
\end{tabular}

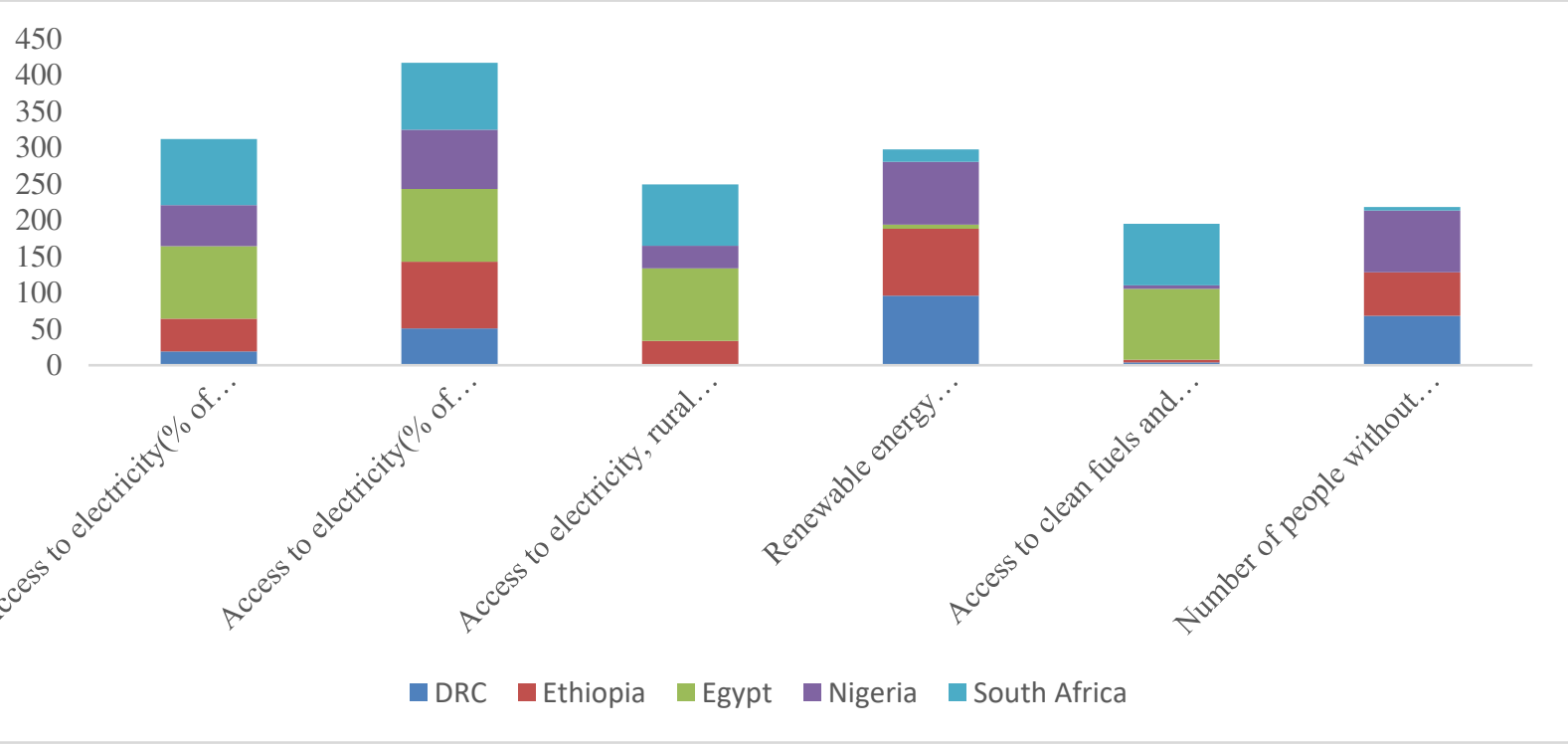


$327 \quad$ Table 3. Total renewable capacities

\begin{tabular}{lccccccccc}
\hline Counntry & 2011 & 2012 & 2013 & 2014 & 2015 & 2016 & 2017 & 2018 & 2019 \\
\hline DRC & 2514 & 2514 & 2515 & 2516 & 2529 & 2551 & 2566 & 2762 & 2772 \\
Ethiopia & 2080 & 2081 & 2224 & 2230 & 2619 & 2649 & 4366 & 4450 & 4450 \\
Egypt & 3503 & 3503 & 3503 & 3503 & 3713 & 3736 & 3857 & 4814 & 5972 \\
Nigeria & 2119 & 2134 & 2136 & 2138 & 2140 & 2143 & 2143 & 2143 & 2152 \\
South & & & & & & & & & 6167 \\
Africa & 997 & 1003 & 1500 & 2710 & 3429 & 4650 & 5587 & 6065 & 6167
\end{tabular}

328 Source, IRENA RES Capacities 2020

\section{$329 \quad 3.3$ Electricity Supply}

330 The electricity supply situation in Africa, particularly SSA, is one of starvation. The study 331 countries except Egypt from North Africa has 100\% electrification, and South Africa above $80 \%$.

332 The rest are less than $80 \%$ making the populace live substandard lives. SSA power sector is 
333 underdeveloped, ranging from installed capacity, overall consumption, and access. The 334 insufficient supply of power has damning consequences on the economies as countries struggle to 335 have sustained economic growth. The GDP per capita growth of countries in Africa with an 336 electrification rate of less than $80 \%$ is relatively low; those whose GDP per capita is more than $337 \$ 3500$ are the natural resources endowed countries(Castellano et al., 2015). Today, about 565 338 million in Africa have no electricity access, and an estimated 900 million people without access to 339 clean cooking fuels and technologies (SEforALL, 2020). Power utilities in SSA Africa find it 340 challenging to meet their mandate regarding Quality, Access, and affordability of services. They 341 are varied reasons attributable to this, but the most common ones are; the inability to find capital 342 to invest in aging infrastructure and the inefficient revenue mobilization rates due to theft, 343 improper billing, and non-payment(Utilities, 2020). Besides, electricity generation in Africa is 344 skewed towards fossil fuels. Africa generates about $81 \%$ of its electricity from thermal sources 345 (Alemzero et al., 2020). Fossil generation exposes the countries to exogenous shocks emanating 346 from the world market due to fossil fuels' importation to power thermals and other related 347 consumption. For Africa to achieve energy security, the continent has to move towards renewables 348 such as Wind and solar and other cleaner energy production sources. Africa's transition to cleaner 349 sources can be achieved through public, private partnerships. Africa's power sector is vertically 350 integrated, making power utilities controlling the generation, transmission, and distribution. 351 However, some countries have started unbundling the power sector, giving concessions to the 352 private sector to participate in the energy terrain (World Bank, 2011). This has injected an efficient 353 management style and the needed finances to the power sector on the continent. According to 354 (World Bank, 2011), the investment required to build transmission lines between 2015 and 2040 355 is around $\$ 3.2$ billion to $\$ 4.3$ billion. More so, Africa has an inadequate transmission lines capacity 
356 to carry large -scale loads to connect consumption centers. Of the 38 countries studied,9 have 357 transmission lines less than $100 \mathrm{Kv}($ World Bank, 2011).

358 DRC is under electrified, given its huge population size. The country has an estimated $50 \%$ of the 359350 gig watts of hydro potential in SSA(Castellano et al., 2015). Most African utilities experience transmission and distribution losses above 50\%, making only power two utilities profitable in 361 SSA(Utilities, 202). The Societe Nationale d'electricite(snel) is the State utility for DRC(Uken, 362 2006), with the primary task of creating electricity access to one of the least electrified countries 363 in the world and Africa. Snel continues to be an indispensable player in energy access but is faced 364 with never-ending commercial losses, high debts, and aging assets(World Bank, 2020.)(Uken, 365 2006). The country has transmission and distribution losses of $36 \%$, which is relatively high from 366 the analysis. That means for every $100 \mathrm{kwh}$ of power produced, $36 \%$ of $\mathrm{kWh}$ is lost. Its total 367 consumption is estimated at 7.43 billion $\mathrm{kWh}$ and has an estimated Peak demand of 1000MW. The 368 grid can carry only $5000 \mathrm{MW}$ due to capacity constraints and saturation. Businesses cope with this 369 demand deficit by having generators to back the poor and unreliable service from Snel. About $37060 \%$ of firms in DRC own generators(World Bank, 2020.) The DRC is already on a sustainable 371 pathway regarding cleaner technologies as it generates a majority of its electricity from 372 renewables, traditional renewable, hydro, about $92 \%$ from hydro. And plans to make it nearly $373100 \%$ in 2030(Selvakkumaran \& Silveira, 2018).

374 Egypt has achieved universal access. From the analysis, the country has Transmission and 375 distribution losses (T\&D) of about 19.9\%. But according to (Elsayed et al., 2018), they reported 376 T\&D losses of about 29\%.On the other hand, (Nassar \& Abdella, 2019) revealed T\&D losses 377 between $11.77 \%$ in 2014 and increased to $12.88 \%$ in 2017 . As reported by the EEHC, the peak 378 load was $17300 \mathrm{MW}$ more than double to $29400 \mathrm{MW}$ in 2017(Nassar \& Abdella, 2019). The 
379 peak load from table 3 is 30800 for 2018 as in the EEHC report(EEHC, 2018). The country has 380 the highest energy consumption among the study country of 159.70 billion $\mathrm{kWh}$. This is plausible 381 since the country is heavily industrialized and achieved universal Electrification. The government 382 targets $20 \%$ of its electricity from cleaner sources by 2022(Nassar \& Abdella, 2019)and has 383 installed renewable energy of 4813 MW. Egypt's power sector uses $50 \%$ of its natural gas, making 384 renewables reduced its energy mix from $13 \%$ in 2010 to $10 \%$ in 2014\%(Mondal et al., 2019). This 385 has shown a decline in the share of RES in the power generation mix. Egypt needs to move to 386 cleaner production sources, given that its fossil fuel sources are depleting(Mondal et al., 2019). 387 The Ethiopian Electricity Company's total installed capacity is 4,206 MW, and the available 388 generation capacity of 4,206 MW.

389 The country has one of the highest T\&D losses of about $23 \%$ and $126 \mathrm{MW}$ of thermal sources. The 390 country relies most on renewables, mostly hydro sources of about 4351. Its peak demand is 391 491MW. It has the least consumed electricity among the study countries of 9.06billio kWh. 392 Ethiopia can transition to cleaner technologies for energy consumption and ensure energy security 393 when it nips corruption in the bud, establishes rule of law, and makes financing 394 available(Akintande et al., 2020). Together with DRC, Ethiopia has about 61\% of Africa's hydro 395 potential on the continent(Olanrewaju et al., 2019). It is no surprise that the two countries have the 396 highest hydropower shares in their electricity generation mix. Nigeria is Africa's most populous 397 country. However, the electricity supply situation there is not encouraging. PHCN has an installed 398 capacity of $12,522 \mathrm{MW}$, with only almost half that available for generation 6,056 MW. The 399 country's total consumption is $24.72 \mathrm{kwh}$ billion and has T\&D losses of $7.4 \%$. As of 2014 , the 400 country's net energy import value was negative, indicating the government did not import energy. 401 Nigeria's renewable capacity is 143MW. Nigeria can transition to cleaner technologies by 
402 attracting foreign direct investment(FDI), the rule of law, strong regulatory 403 environment(Akintande et al., 2020); in contrast, this transition to cleaner technologies can be 404 hampered by corruption, political instability, and the presence of violence (Akintande et al., 2020). 405 According to (Ugwoke et al., 2020), in the third quarter of 2018, Nigeria had installed a cumulative 406 generation capacity of $13,435 \mathrm{MW}$. The available power was $8,200 \mathrm{MW}$ and a peak demand of 407 5,162MW. As alluded to by the Nigerian Electricity Regulatory Commission (NERC), the 408 distribution companies(DISCOs) could not account for $1.9 \mathrm{kwh}$ of $10 \mathrm{kwh}$ of power sent from the 409 Transmission System Provider(TSO) in the third quarter of 2018(Ugwoke et al., 2020). This 410 represents a loss of $\$ 1.90$ of every 10 received as a result of malfunctioning infrastructure due 411 to technical challenges and light theft(Ugwoke et al., 2020). South Africa is a driver of renewable 412 energy additions in SSA. The country has an installed capacity of 51,309MW. And about 46,776 413 MW disproportionally coal. Eskom controls and produces about $90 \%$ of South Africa’s electricity, 414 and the rest is produced by Independent power producers (IPPs) and municipalities(Bohlmann \& 415 Inglesi-lotz, 2018). Eskom has 28 power generation units, with a cumulative capacity of $41642,810 \mathrm{MW}$ and the IPPs have a nominal capacity of $3392 \mathrm{MW}$ and South Africa in 2016 generated 417219 979GWh(Bohlmann \& Inglesi-lotz, 2018). Table,4 provides total electrity consumption, 418 power utilities and their installed capacities.

419 Table 4 Total Electrity Consumption, Power Utilities and their installed capacities

\begin{tabular}{|c|c|c|c|c|c|}
\hline & $\mathrm{DRC}$ & Egypt & Ethiopia & Nigeria & $\begin{array}{l}\text { South } \\
\text { Africa }\end{array}$ \\
\hline \multirow{4}{*}{ Utility Company } & Societe & Egyptian & Ethiopian & Power Holding & \multirow{4}{*}{ Eskom } \\
\hline & Nationale & Electricity & Electric & Company of & \\
\hline & D'electricite(snel & Holding & Utility(EEU & Nigeria(PHCN & \\
\hline & ) & Company(EEHC) & ) & & \\
\hline $\begin{array}{l}\text { Installed Generation } \\
\text { Capacity (MW) }\end{array}$ & 2579 & 58353 & 4,244 & 6,056 & 51,309 \\
\hline Total & 2,677 & 58353 & 4,206 & 12,522 & 51,309 \\
\hline Thermal(MW) & 318 & 51226 & 126 & 10,142 & 46,776 \\
\hline Renewables & 2750 & 4813 & 4351 & 2143 & 6065 \\
\hline
\end{tabular}




\begin{tabular}{lccccc} 
Total Electrity Consumption & DRC & Egypt & Ethiopia & Nigeria & $\begin{array}{c}\text { South } \\
\text { Africa }\end{array}$ \\
\hline Consumption(kWh)Billion & 7.43 & 159.7 & 9.06 & 24.72 & 207.1 \\
Losses(\%) 2015/16/18 & 36 & 19.89 & 23 & 7.4 & 8.59 \\
Net energy imports(of Energy use), 2014 & 1.95 & -7.39 & 5.92631 & -93.0272 & -14.484 \\
\hline
\end{tabular}

\section{Democratic Republic of Congo (DRC)}

423

424 The Democratic Republic of Congo(DRC) is a vast country with about ten million households and 425 nearly 1.6 million having access to electricity. It is the third most populated country with people 426 having less access to electricity. If the trajectory continues as a business as usual approach, $80 \%$ 427 or 84 million people will live without electricity in the DRC by two decades from now(World 428 Bank DRC,2020.)Today, the country's electrification rate is 19\%, with nominal consumption in 4292018 at $8349 \mathrm{GWh}$. The average price of electricity in the country goes for $0.07 \mathrm{US} \$ / \mathrm{kWh}$. Hydro 430 accounts for $98 \%$ of the 2,579 installed capacity in 2018, and fossil fuels making up $2 \%$. The 431 country's power sector faces many challenges ranging from low generation capacity, limited and 432 disjointed networks, institutional inefficiency, and low electrification rate(Smillie, 2013). The 433 country's hydropower potential is about $40 \mathrm{GWh}(\mathrm{Smillie}, 2013)$. The DRC plans to finish 434 constructing the grand Inga 3 bases Chute Dam as well as reduce its greenhouse gas 435 emissions(GHG) by $17 \%$ in 2030 relative to BAU approach by (430 $\mathrm{Mt} \mathrm{CO}_{2}$-equivalent), nearly 436 more than $70 \mathrm{Mt} \mathrm{CO}_{2}$ reduction(Energy \& Special, 2019).DRC is a significant leading producer 437 of cobalt in the world and makes up two-thirds of the global supply, necessary for the energy 438 transition(IEA Africa, 2019).

\section{Egypt}


440 The Cleaner production concept has gained traction globally. Egypt has responded to that by

441 promulgating law 4 on the environment in 1994 to bring to the fore issues about the ecosystem

442 such as pollution, emissions and to address them(Hamed \& El Mahgary, 2004). Egypt's energy

443 sector faces the challenges of increasing energy demand and the over-reliance on fossil fuel 444 consumption. The country's energy strategy aims to achieve energy security and 445 efficiency(Mondal et al., 2019). Egypt currently generates about two-thirds of its electricity from 446 gas. The energy sector consumes more than $50 \%$ of the country's gas, with renewables reducing 447 the energy mix from 13\% from 2010 to $10 \%$ in 2014(Mondal et al., 2019). However, Egypt is 448 faced with the hurdle of meeting home increasing demand even as productions are dwindling. The 449 country's oil consumption outstrips its production, making crude oil consumption increased by $45016 \%$ in 2007, in the region of 802,00 barrel per day in 2017(US EIA, 2018). This gives an energy 451 insecurity situation for the country and needs to be addressed with renewables consumption. Egypt 452 has good potential for solar as well as abundant Wind resources (US EIA, 2018). As a result, the 453 Egyptian Electricity Holding Company(EEHC) has initiated steps to increase renewable energy 454 resources(RES) to the power generation mix by $20 \%$ in 2022 , by the end of 2022 . Some of the 455 conventional power plants would be shut down, with steam plants reducing from $43 \%$ to $31 \%$ and 456 that of gas and combined plants reduced from $14 \%$ to $13 \%$ and $33 \%$ to $28 \%$, respectively(Nassar 457 \& Abdella, 2019).

458 Ethiopia

459 Ethiopia's long term vision strategy is to ensure the development of affordable, clean, and 460 modern energy and access for the rapid social and economic growth and structural transformation 461 as well as for all citizens and become a renewable energy hub in the Eastern Africa Region by 462 2025(Government of Ethiopia, 2020). Ethiopia is one of the leading countries with robust 463 economic performance in the East Africa Enclave. It is equally a major renewable energy exporter 
464 to the east Africa Power pool. It sends renewable energy to Sudan and Djibouti through a 230kv, 465 with power flowing up to $250 \mathrm{MW}$ and 90 M.W., respectively(Beyene et 2018.) And aiming to 466 invest about $20 \%$ of yearly budgetary allocation on infrastructure in the energy, railway, and 467 telecommunication sectors(Government of Ethiopia, 2020). About $90 \%$ of Ethiopians rely on 468 biomasses for cooking (Guta, 2020). Amid these statistics, the country had a 44\% electrification 469 rate in 2018 and a national nominal consumption rate of 9,042 Gwh in 2018. The average 470 electricity price is $0.03 \mathrm{USDkwh}$.

471 Furthermore, its installed generation capacity is 4,244MW in 2018, with hydro forming $90 \%$ 472 and Wind energy 8\% (African Energy portal,2020). Ethiopia's hydro potential is estimated at $47345 \mathrm{GW}$, the prospect of Wind is $10 \mathrm{GW}$, and geothermal is $5 \mathrm{WG}$ (Hossain et al., 2014). Ethiopia 474 aims to attain GDP per capita by 1000 in 2030 and reduce economy-wide greenhouse gases(GHG) 475 from $400 \mathrm{Mt}-\mathrm{CO}_{2} \mathrm{eq}$ in 2030 to $145 \mathrm{Mt}-\mathrm{CO}_{2} \mathrm{eq}$ in about two decades in a business as usual 476 approach. (Selvakkumaran \& Silveira, 2018).

\section{$477 \quad$ Nigeria}

478 Energy demand in Nigeria is increasing at an exponential rate. The trend is set to continue in 479 the years to come as the country is expecting population growth. The country generates most of its 480 electricity from conventional sources. $86 \%$ of its generation comes from hydro sources and $14 \%$ 481 from thermal(Government of Nigeria, 2020). Its average electricity price is 6USDckWh.Access to 482 electricity was $54 \%$ in 2017 , and final energy consumption was 25,537 Gwh in 2018 . Losses 483 recorded in the transmission network were 16\% in 2014. (AEP,2020). Total generation capacity 484 in 2018 was 13,560 MW.20\% of the electricity is generated by the private sector, and demand 485 growth per year 7\%. Peak demand is estimated at $12.8 \mathrm{GW}$, with a 7.7 generation 486 deficit(Government of Nigerian, 2020). The transmission sector is vertically controlled by the 487 state, with the transmission Company of Nigeria (TNC) under a management contract with the 
488 Manitoba Hydro International, which was contracted to reduce the transmission and distribution 489 of the TNC.

490 South Africa

491 South Africa is the second biggest economy in Sub-Saharan Africa. It has made notable 492 progress in its socio-economic life since the end of the apartheid era. However, there is still a vast 493 income disparity and high unemployment prevailing in the country. The Gini coefficient for South 494 Africa in table 1 is the highest among the study countries. South Africa is the world's 14th emitter 495 of $\mathrm{CO} 2$ due to its over-reliance on coal consumption. The energy sector is faced with numerous 496 challenges, such as supply deficit, load shedding, and Eskom's financial difficulties. The country's 497 leading electricity provider and, as of 2019, South Africa had about 56,392MW installed 498 generation capacity. The IPPs had about 5,492MW of installed generation capacity and a peak 499 load of 34,256MW(Roche et al., 2020). South Africa's energy mix is tilted toward coal, which is 500 about $73 \%$, and will continue to be a larger part of the energy mix up to 2024. The Wind is roughly 501 about $3.8 \%$, Solar 3.6\%, and hydro 6.4\%. These capacities were delivered through the Renewable 502 energy independent power procurement program (REIPPP)(Roche et al., 2020)

\section{4. Cleaner Energy Potential}

504 Cleaner energy sources are the panacea to the energy insecurity situation in African and in the 505 study countries. The natural resource rich countries such as ; Egypt, Nigeria, and the like are 506 facing dwindling reserves due to increased domestic consumption and the finite nature of 507 conventional energies. For these countries to have energy security and sustainably meet the 508 increasing demand and create green jobs and reduce carbon dioxide emissions, renewable energy 509 consumption is the best way to pursue.Distributed Renewables Energy access(DREA) is the most 510 sure means to ensure energy access and benefited about 150 millionin 2019(REN21, 2020) 
Solar energy has a vast potential to meeting the energy needs of African countries. Africa is

513 the most solar endowed continent. Solar costs have plummeted drastically over the decades, 514 making solar cost competitive to fossil fuel plants. According to the (IRENA 2019), the generation 515 cost of solar and Wind have fallen by $16 \%$ and $3 \%$ since 2010 . Despite these falling costs, most 516 African countries have not scale up due to limited institutional capacity, lack of scale, lack of 517 competition, high transaction costs, and high understood risks. Solar is focused, according to the 518 IEA (RES4, 2020), to make up about $63 \%$ of electricity generation in SSA by 2040 , while non519 hydro sources are constituting $37 \%$ for the Africa case scenario (RES4, 2020). Solar and Wind are 520 anticipated to be the leading emerging technologies consisting of a bulk of the installations. Solar 521 P.V. could reach $124 \mathrm{GW}$ by 2030 and 316 by 2040; on the other hand, Wind could reach $51 \mathrm{GW}$ 522 and 94 G.W. to power grids in Africa by 2030 and 2040(RES4, 2020).According to the 523 (Bloomberg NEF, 2020), there is about 62\% forcasted gowth in Solar PV installations in 2021 524 than in 2018, in SSA. The DRC, for instance, has a vast and different potential for renewables. 525 The potential for solar is spread across the entire country, and Wind is located around the country's 526 eastern part. According to the (IRENA 2019), Africa can significantly generate a quarter of its 527 energy consumption from local and clean energy sources by 2030. Clean energy sources making 528 up $310 \mathrm{GW}$ can satisfy about half of the continent's electricity generation demand (IRENA, 2019).

529 South Africa intends to generate $8.4 \mathrm{GW}$ by 2030 . The country equally has an estimated 194,000 $530 \mathrm{~km} 2$ of strong solar radiation potential in the Northern Cape, which is noted globally for solar 531 potential, and solar anticipates to make up 14\% of electricity generation by 2050(Aliyu et al., 532 2018). Egypt has rich solar energy. It is among the global Sunbelt countries. As (Aliyu et al., 2018) 533 revealed, the government had on about 3200h sunshine of annual direct energy intensity of 1970$534 \quad 3200 \mathrm{~kW} \mathrm{~h} / \mathrm{m} 2$ and the technical solar generation electricity potential of 73.6Petawatt(Aliyu et al., 
535 2018). Africa's leading total installed capacities for Wind and solar in 2018 was South Africa with

$5361.8 \mathrm{GW}$ and $2.1 \mathrm{GW}$, and third in concentrated Solar thermal power(CSP) in the world, with 537 400MW(RES4, 2020).

538 Nigeria has the mean daily radiation of $14.4 \mathrm{MJ}$ m-2 day-1 in the southern part and $21.6 \mathrm{MJ}$ $539 \mathrm{~m}-2$ day-1 prevailing in the northern region. If Nigeria can utilize $1 \%$ of its land area with the 540 mean 6 hours a ray of daily sunshine for P.V. power, it could generate about 1850,000 GW h 541 yearly(Aliyu et al., 2018. Ethiopia equally has good potential for solar. Its solar radiation is around $5425.2 \mathrm{kWh} / \mathrm{m} 2 /$ day, conducive to the deployment of utility-scale solar, and the government targets 543 to install $500 \mathrm{MW}$ of solar by 2020(Dorothal, 2019). The country currently installs bout $14 \mathrm{M}$.W. 544 of solar, but the increase has been steady yearly(Dorothal, 2019).

\section{$545 \quad 4.2$ Wind}

Africa deploys wind energy to tackle the hydra-headed challenges of energy security, 547 sustainable generation, and green job creation. The continued fall in wind energy costs makes it 548 more compelling economically to scaling up deployment in Africa. Thus, it is not only an 549 economic justification to deploy Wind in Africa but a political reason to meet the Paris Accord. 550 Countries with the most wind installations on the continent are in the northern and southern parts. 551 The continent is addressing the socio-economic and environmental issues facing the sector for it 552 to take off. South Africa is a driver of Wind energy capacity in Africa. The country had more than $5532 \mathrm{GW}$ of installed wind capacity in 2019 and above $3 \mathrm{GW}$ of planned capacity through the REIPPP 554 and targets to make Wind generates $17.8 \%$ of electricity in 2030(RES4, 2020). The technical wind 555 potential of South Africa Energy (TWh/year) with no grid restriction is 6306.7Twh, and with grid 556 restriction is $6040.7 \mathrm{Twh}$. Its capacity greater than $20 \%$ can generate about $4773.3 \mathrm{Twh}$ (Mentis et 557 al., 2015). This analysis shows that South Africa has massive potential for wind energy. 
On the other hand, DRC has 450.1TWh yearly generated power without grid restrictions and 559 378.9Twh with grid restriction and a capacity factor greater than $20 \%$ generation of 20.4 Twh 560 yearly(Mentis et al., 2015). This correctly describes DRC'S wind energy potential as the Wind 561 energy potential is more promising in its eastern part. Furthermore, Egypt is endowed with one of 562 Africa's most significant wind speeds for generating wind energy. Egypt's yearly energy 563 generation from Wind without restriction is estimated at 5155.9Twh and with grid restriction is 564 3560.8Twh yearly. The capacity factor greater than $20 \%$ generation is 2724.3 Twh(Mentis et al., 565 2015). Ethiopia equally has an enormous wind potential as the generation yearly without grid 566 restriction is estimated at $1159.7 \mathrm{Twh}$, and the capacity factor greater than $20 \%$ gives a yearly age of 238.9Twh(Mentis et al., 2015). The country experiences wind speed more than $8 \mathrm{~m} / \mathrm{s}$ in certain 568 areas required for utility-scale wind generation. Nigeria has a wind energy potential of $56950,046 \mathrm{MWh} /$ year, with better rates along the coasts and offshore(Government of Nigeria, 2020).

$570 \quad 4.3$ Hydropower

571 Africa has a lot of hydro resources. Africa's hydro potential is about $12 \%$ of the global hydro 572 potential(RES4, 2020). The continent's hydropower is estimated at 1750GW(RES4, 2020). 573 Nigeria plans to install 2 G.W. of hydro sources by 2025. (Aliyu et al., 2018). Nigeria equally has $5741,4750 \mathrm{MW}$ of hydro potential with an installed capacity of $1,930 \mathrm{MW}$, representing only $14 \%$ of 575 the total installed(Government of Nigeria, 2019).In South Africa, the hydro potential is 576 4,000GWh/year(Roche et al., 2020). The DRC has the most significant hydro potential in Africa, 577 estimated at $774 \mathrm{GW}$. It can generate revenue of over $6 \%$ to its GDP(Atlas Africa, 2017). The 578 country has only exploited its economically feasible level of $3 \%$, and it provides nearly a hundred 579 percent of its electricity(Atlas Africa, 2017). Hydro supplies about $88.9 \%$ of Ethiopia's electricity 580 and has an economically viable hydro reserve of 45,000MW(Government of Ethiopia, 2019.) 581 .Egypt relies mostly on fossil fuel sources. Egypt's total installed capacity for hydro as in 2019 
582 stood at $2832 \mathrm{MW}(\mathrm{EEHC}, 2018)$.Hyropower froms about 12\% of the Egypt's electricity

583 consumption.(Aliyu et al., 2018).

$584 \quad 4.4$ Bioenergy

585 Bioenergy is the energy that is gotten from the processing of Biomass. It is a dominant fuel in 586 Africa and can generate significant power for national consumption. The DRC has the potential 587 for bioenergy due to its 125 million hectares of forest, representing $67.7 \%$ of its land's surface and 588 plant and animal waste(Atlas Africa, 2017). However, the issue has to do with the cost of buying 589 digesters and installing them since most people are low income earners(Atlas Africa, 2017). South 590 Africa has the potential for bioenergy around the Kwa-Zulu natal and Mpumalanga. (Aliyu et al., 591 2018). Furthermore, Egypt has the potential for bioenergy with about 2 or 3 times crop yield 592 seasons and alot of animal waste and municipal solid waste. (Aliyu et al., 2018) Municipal waste 593 was estimated to 15.3 million tonnes in 2001 , with $75 \%$ generated from urban centers (Aliyu et 594 al., 2018). In addition, Ethiopia has great bioenergy, as estimates put the national woody biomass 595 to be 1,149 million with a yearly yield of 50 million tonnes in 2000 . The country equally has sugar 596 cane plantation needed for bioenergy(Atlas Africa, 2017)

$597 \quad 4.5$ Geothermal Energy

598 Geothermal energy is limited to a select few countries in the African continent; Kenya is 599 leading the way. However, Ethiopia has geothermal energy with 7.3 MW by the end of 2011. The 600 resource potential is at the Rift Valley, and the Afar depression has immense potential and can 601 generate about 5000MWe of electricity(Atlas Africa, 2017). Nigeria has the potential for 602 geothermal, according to recent studies carried out in selected states in Nigeria(Atlas Africa, 603 2017). And South Africa reliance on coal shows the country has no utility-scale geothermal energy 604 production in the country(Atlas Africa, 2017).

\section{3. Methodology}


To carry out this research, data from the world development Bank development Indicators and

607

608

609

610

611

612

613

614

615

616

617

618

619

620

621

622

623

624

625

626 627 for a country. The more a country depends on external sources to meet its energy needs, the more 628 vulnerable the country is to negative exogenous shocks such as oil price volatility and other market

Big five"' of African countries. These are the most populous of the African countries from the period 2001-2019. The variables were obtained relevant to our analysis, with renewable energy consumption as a percentage of total consumption being the dependent Variable. The essence for selecting this dependent Variable is to see how the factors will influence or cause the upscale of renewable energy capacity in Africa. Given that African countries have put in measures to scale up renewables deployment on the continent, with the formation of the African renewable energy initiative (AREI). It is coded as _RESCON. The rest of the independent variables are electricity consumption from fossil fuel sources (EFOS). This Variable was selected to determine the correlation between renewable energy consumption on the continent. It stands to reason that, if fossil fuels are used for generating electricity, then there is the need to increase renewables consumption for electricity generation. Hence there is an inverse relation relationship between these two variables. Another independent variable is access to clean fuels and technologies for cooking (\% of the population).

Most Sub Saharan Africans Access to these clean cooking technologies is very abysmal, having harmful effects on the population. Hence the need to measure it with renewables consumption. A direct relationship is expected between them. It is coded as CleanT\&FC. Of course, the big elephant in the room is Electrification; all these variables can't be measured without people having access to electricity. Access to clean electricity, especially renewables, is very key to ensuring energy security on the continent. Indeed, Energy imports have security implications 
629 shocks. The correlation is anticipated to be a positive one. It is coded as Eneimprt. Another 630 important variable is that of the Quality of the regulatory environment operating in the country. It

631 shows how the government can formulate and implement sound regulations and policies for 632 effective private sector participation and development. It is encoded as regquality, And finally, 633 effective compliance talks about the Quality of government policies, free interference from 634 political actors in state institutions, and government credibility to see such policies come to 635 fruition. As the literature has revealed and given the theoretical basis for the analysis, a pooled 636 model at the firm level is used as done in (García-Álvarez et al., 2017). At first, we thought of 637 applying a panel data methodology such as the GMM model pioneered by Arellano and Bond for 638 dynamic panel data models(García-Álvarez et al., 2017). Using that methodology would mean the 639 number of instruments would be more than the number of countries as alluded to by (García640 Álvarez et al., 2017). The model estimated is given below:

$$
X_{i t}=y_{o}+\beta x_{i t}+\sum_{t=2001}^{2019}+\varepsilon_{t}
$$

642 Where $X_{i t}$ is the vector of the independent variables in the equation. If the equation is subject to 643 reparameterization, it takes the form, 

variables, which estimates the impact of the independent variables on the percentage of renewables

656 in final energy consumption? The stochastic term $\varepsilon_{i}$ are distributed across the years, country, and

657 has a zero mean and constant throughout. Interaction occurs when the independnent Variable has

658 a different impact on the outcome reacting to the values of another independent variable. When 659 the interaction is created the effect on one Variable depends on the level of the other 660 Variable.Therefore an interaction is created on the equation below: The possible equation for the 661 three variable interaction is showed below.

$$
\operatorname{RESCCONS}_{i}=Y_{1}+\beta_{1}+\beta_{2} \operatorname{CLEAN}-F_{i}+\beta_{3} \operatorname{CO2}_{i} \beta_{4} \text { EFFECTCOMP }_{i}+
$$

$663 \beta_{5}$ REGQUTY $_{i} \beta_{6}$ EFOS $_{i} \beta_{7}$ ELECTRIFICAT $_{i} \quad \beta_{8}$ ENEIMPRT $_{i} \quad \beta_{9}$ GDPGRWTH $_{i} \beta_{10}$ CLEAN -

$664 F C * E^{2} F O S_{i} * R E G Q U L T Y+\sum_{2001}^{2019}+\varepsilon_{i}$

665 From equation three 3. A three variable interaction is being made among EFOS,CLEAN_FC and 666 REGULTY.

\section{3.1 First generation Panel Root test}

668 Estimators are inefficient if the varibles in the panel are nonstationary unless they are 669 conintegrated.How can one know whether the variables are stationarty or not? We applied the frist 670 generation panel root tests, such as Hadri (2000), Levin et al. (2002, LLC), 2003, IPS) Fisher-

671 ADF (Choi, 2001), states that cross section independence or homogenuity of the units:In addition, 672 all the first generation unit root tests test for null hypothese of the root unit,except Hadri test. The 673 equation is specified below: 


$$
\Delta y_{i, t}+a_{i}+p y_{i, t-1}+\sum_{k=1}^{n} \Phi_{i} \Delta y_{i, t-1}+\delta_{i} t+\theta_{t}+\varepsilon_{i}, t
$$

675 From the equation (4) $i=1,,,, \mathrm{~N}$ and $T=1, \ldots, T$. The stocahstoc terms $\varepsilon_{i}, t$ i.i.d $\left(0, \delta^{2} \varepsilon i\right)$ are 676 said to be independent across the uits of the sample(Hurlin \& Mignon, 2007). Do they have the 677 same panel root process with

$$
H_{o}: \rho<1
$$

Verses $\quad H_{A}: \leq 1$

The Null hypothesies of the panel root test assumes that $Y$ variables are stationary, and the alternative says $Y$ variables are nonstationary.Difference in unit roots:No unit root.

$$
t_{1 P S}=\frac{\sqrt{N}\left(t-1 \frac{1}{N} \Sigma_{K=1}^{N} E\left[t_{i T} \mid \rho_{i=0}\right]\right)}{\sqrt{\left.\frac{1}{N \sum_{K=1}^{N} \operatorname{var}\left[\left[t_{i T} \mid \rho_{i=0}\right]\right.}\right]}} \Rightarrow N(0,1) \text { Fisher }
$$

\section{A second generational Panel root test}

A second generation panel root tests waters down the cross sectional independence assumption. In order to respond to ways to deal with the panel root tests, dealing with cross section dependence. For the puropses of this study, we have used the second generation tests by the Bai and $\mathrm{Ng}(2001$,

687 2004), Im, pesaran and Shin Unit root test( 1993 \&2003). Bai and $\mathrm{Ng}(2001,2004)$ proposed the 688 first test for unit root tests for the null hypotheses taking cognizance of the cross sectional 689 dependence.They suggested the following factor analytical approach.

$$
y_{i, t}=D_{i, t}+\curlywedge_{i}^{\prime} F_{t}+e_{i, t}
$$

$691 D_{i, t}$ denotes the plynomial time function of ordere $t, F_{t}$ is a real(r,1) vector of common factors, 692 and $\iota_{i}^{\prime}$ is a vector of factor laodings. Hence the individual series $y_{i, t}$ is broken down into different 693 heterrogenous determinisitic parts, $D_{i, t}$ is a common part of $\kappa_{i}^{\prime} F_{t}$, and $e_{i, t}$ is the stochastic term, 694 which is mainly indiosyncratic.In the equation (5) above, $y_{i, t}$ nonstationary, if thr common factor 
695 of the vector $F_{t}$ is non stationary or the error term $e_{i, t}$ is nonstationary.Furthemore, it is not certain 696 that some will have stationarity and others will not.Other components of $F_{t}$ couldbe $\mathrm{I}(0)$ and the 697 rest of the $1(\mathrm{I})$ and others at different orders integrated. Another test for the cross section 698 dependence is the Im, pesaran and Shin Unit root test( 1993 \&2003), from that time came the IPS

699 (Hurlin \& Mignon, 2007). From the equation below, Unlike the LL test approach, this method 700 allows for heterrogeunity in the value of $\rho_{i}$ in the alternative hypotheses. The IPS adapts the model 701 (1), and changes $\rho_{i}$ for $\rho$ a model with trend and no time individual effects is shown below:

702

$\Delta y_{i, t}=a_{i}+\rho_{i} y_{i, t-1}+\sum_{z=1}^{\rho_{i}} \beta_{i, z} \Delta y_{i, t-z}+\varepsilon_{i, t}$

703 From the model, the null hypothesis is given as $H_{o}: \rho_{i}=0$ for all is equal to $i=1, \ldots N$ aandthe 704 alternative hypothesis is given as $H_{1}=\rho_{i}<0$ for $i=1, \ldots \ldots, N_{1}$ and $\rho_{i}=0$ for $i=0=N_{1}+$ 705 $1, \ldots, \mathrm{N}$ with $0<N_{1} \leq \mathrm{N}$. The other hypotheses make room for individual hypotheses to have unit 706 $\operatorname{root}($ Hurlin \& Mignon, 2007).The IPS uses a separate unit root tests for the $\mathrm{N}$ cross section units,

707 rather than pooling them. The tests is grounded on the the augumented Dicker Fuller statistics mean 708 groups(Hurlin \& Mignon, 2007). The testing of quantile long-term equilibrium impact of energy 709 consumption on ecological disorder is ensured through the QARDL model. The Wald test is also 710 used to assess The time-varying integration relationship as follows:

$$
E C_{t}=\alpha+\sum_{i=1}^{p} \varphi_{i} E C_{t-i}+\sum_{i=0}^{q 1} \omega_{i} G_{t-i}+\sum_{i=0}^{q 2} \lambda_{i} G D P_{t-i}+\sum_{i=0}^{q 3} \theta_{i} K_{t-i}+\varepsilon_{t}
$$

$$
C O_{2}=\alpha(\tau)+\sum_{i=1}^{p} \varphi_{i}(\tau) C O_{2}+\sum_{i=0}^{q 1} \omega_{i}(\tau) G_{t-i}+\sum_{i=0}^{q 2} \lambda_{i}(\tau) G D P_{t-i}+\sum_{i=0}^{q 3} \theta_{i}(\tau) K_{t-i}+\varepsilon(\tau)_{t}
$$




$$
\gamma_{G}(\tau)=\sum_{i=0}^{q 1} \omega_{i}(\tau), \quad \delta_{G_{i}}=-\sum_{j=i+1}^{q 1} \omega_{i}(\tau)
$$

$$
\gamma_{G D P}(\tau)=\sum_{i=0}^{q 1} \lambda_{i}(\tau), \quad \delta_{G D P_{i}}=-\sum_{j=i+1}^{q 1} \lambda_{i}(\tau)
$$

$$
\gamma_{K}(\tau)=\sum_{i=0}^{q 1} \theta_{i_{i}}(\tau), \quad \delta_{K_{i}}=-\sum_{j=i+1}^{q 1} \theta_{i_{i}}(\tau)
$$

718

\section{Results and Discussion}

720

721

722

723

724

725

726

727

728

729

730

731

Table.5 Pooled Effects Regression

\begin{tabular}{lrcrr}
\hline Variable & Coefficient & \multicolumn{1}{c}{ Std. Error } & t-Statistic & Prob. \\
\hline CO2 & -1.45968 & 0.231227 & -6.31275 & 0 \\
EFFECTCOMP & -0.02974 & 0.057026 & -0.52147 & 0.6034 \\
ELECTRIFICAT & 0.598742 & 0.127169 & 4.708233 & 0 \\
ENEIMPRT & 0.097498 & 0.048608 & 2.005794 & 0.048 \\
GDP_GROWTH & -0.17968 & 0.074408 & -2.41477 & 0.0179 \\
REGQULITY & 0.094006 & 0.054233 & 1.733351 & 0.0866 \\
R-squared & 0.983777 & Mean dependent var & & 60.81072 \\
\hline
\end{tabular}

From the table, 5 it is apparent from the analysis that access to clean fuels and technologies is very perfectly significant, showing a strong correlation to the dependent Variable. This is because clean cooking more or less has to do with distributed generation and from Liquefied natural gas(LPG) then with Electrification. Fewer people cook with electricity in Africa, even though they are connected to the grid(Jewitt et al., 2020)(Dagnachew et al., 2019). Due to the high cost of the ecook method, most rural dwellers cannot afford them(cooking with Electricty, 2020). This, however, makes a strong point that Africa needs to transition to renewables energy consumption, which is sustainable and healthier to consume. Also, $\mathrm{CO}_{2}$ emission levels is a major factor to be considered. It is strongly significant. This explains the reason why the world wants to transition to 
732 renewables consumption. It is the main greenhouse gas (GHG) that causes climate change. Even

733 though Africa's general emission levels are generally lower relative to the rest of the world(IEA

734 Africa, 2019), South Africa is the first emitter in African and fourteen in the world. But an

735 interesting result relationship is that it is having a negative correlation to the dependent Variable.

736 It was indicating an inverse relationship.

737 This result was also gotten by (da Silva et al., 2018). The correlation means as $\mathrm{CO}_{2}$ increases, 738 renewables consumption decreases. South Africa relies on coal about $80 \%$ to generate electricity, 739 emitting so much $\mathrm{CO}_{2}$ (Edkins et al., 2010). The effectiveness of compliance is a major factor in 740 considering how effective state institutions are and their independence from political interference.

741 It came out not significant in the analysis. Another variable that met anticipation before the analysis

742 is _EFOS, which is electricity generated from fossil fuel sources. A country that generates a bulk 743 of its electricity from fossil fuel sources should strive to switch and generate more renewables.

744 This will make the country dependent on local resources and not be exposed to geopolitical risks 745 in the energy market. Indeed a variable that equally satisfied our curiosity during the analysis is 746 the electrification rate. It came out perfectly significant. As some of the study countries don't have 747 universal access, it is expected that they will embrace and scale up renewables to achieve this 748 objective, as the Paris Accord envisages(IRENA, 2019) and (Olanrewaju et al., 2019). Furthemore, 749 the correlation is a positive one, meaning as electrification rate increases, renewables consumption 750 of total energy consumption increases (Sun et al., 2020).

751 Besides, another variable that came very significant is ENEIMPRT. It is highly significant and 752 directly correlates to renewable energy capacity - all other things; being equal, when energy 753 imports increase, renewable consumption increases. As a country imports energy to meet its 754 domestic demand, it exposes the country to adverse exogenous shocks and economic ramifications 
755 (Alemzero et al., 2020). For instance, importing countries are exposed to oil price volatility making

756 economic planning difficult(Alemzero et al., 2020). Besides, GDP_GROWTH was significant in

757 determining the relationship with the dependent Variable, renewable energy consumption.

758 However, the correlation is negative, implying that the countries have decoupled their economic

759 growth from energy consumption. And so, as the economy grows, energy demands reduces,

760 creating an inverse relationship.

761 Finally, the Quality of regulatory environment prevailing in a country; REGQULITY is significant

762 as was anticipated. For renewables to scale up in the "Big five"' countries in Africa, there has to

763 be a robust regulatory environment to ensure that policies are implemented to encourage and

764 promote private sector participation in the renewables sector. (IRENA, 2019)

Table.6 Total panel (balanced) observations

\begin{tabular}{lrrrr}
\hline Variable & Coefficient & \multicolumn{1}{c}{ Std. Error } & \multicolumn{1}{c}{ t-Statistic } & \multicolumn{1}{c}{ Prob. } \\
\hline C & 97.56274 & 2.006324 & 48.6276 & 0 \\
CLEANT_FC & -1.20878 & 0.097505 & -12.3971 & 0 \\
CO2 & -1.44447 & 0.230685 & -6.26164 & 0 \\
EFFECTCOMP & -0.04992 & 0.062976 & -0.7927 & 0.4301 \\
EFOS & -0.37911 & 0.07452 & -5.08733 & 0 \\
ELECTRIFICAT & 0.615831 & 0.127944 & 4.813294 & 0 \\
ENEIMPRT & 0.099424 & 0.04852 & 2.049117 & 0.0435 \\
GDP_GROWTH & -0.16906 & 0.073344 & -2.30502 & 0.0236 \\
REGQULITY*EFOS*CLEANT_FC & $1.51 \mathrm{E}-05$ & $8.03 E-06$ & 1.879338 & 0.0636 \\
Root MSE & 5.154061 & R-squared & & 0.983873 \\
Mean dependent var & 60.81072 & Adjusted R-squared & 0.982372 \\
\hline
\end{tabular}

766 From table 6 above the three variable interaction terms is created to determine the effect on the

767 dependent variable, renewable energy consumption, as a percentage of total energy consumption.

768 The variables that are interacted are REGULTY, EFOS, and CLEANT_FC. The results proved the 769 same significance levels as in the pooled OLS in the first equation. Effective compliance was not

770 significant, as in the first equation. These shows the results are robust. It must be noted that the 771 interaction term is significant. This implies that the interaction of regulation quality, Electricity 
772 generation from fossil fuel sources, and access to clean fuels and cooking technologies impacts the

773 scaling up of renewables in Africa positively. More so, the direction of the relationship is a direct

774 relationship. The correlation, therefore, implies that when renewables capacity increases, the

775 interaction term increases. In essence, when any of the study countries generate more electricity

776 from fossil fuels, has a good regulatory environment as well as the need for increased access to

777 clean cooking fuels and technologies, it is very imperative for the country to increase the

778 deployment of renewables.

\section{$779 \quad 4.1$ Unit Root Test Analysis}

780 Overall, the results of the stationarity test of the variables are presented in table 7 below. We

781 adopted the first generation unit root test of Hadri (2000), Levin et al. (2002, LLC), 2003,

782 IPS) Fisher-ADF (Choi, 2001) and Hadri (2000). The results from table three show that all the

783 variables have unit root at level and therefore non stationarity.However, after taking their first

784 difference, the variables became stationary at I (1) and therefore we accept the alternative

785 hypothesis that the variables have no root unit and reject the null there that there is unit root in as

786 depicting in table 7.

787 Table 7 Stationarity test of the variables

\begin{tabular}{llcccr}
\hline Variable & $\begin{array}{l}\text { LLC } \\
\text { Constant }\end{array}$ & $\begin{array}{l}\text { PP-Fisher } \\
\text { constant }\end{array}$ & $\begin{array}{l}\text { Fisher-ADF } \\
\text { constant }\end{array}$ & $\begin{array}{c}\text { IPS } \\
\text { constant }\end{array}$ & $\begin{array}{r}\text { Hadri } \\
\text { constant }\end{array}$ \\
\hline Rescons & 0.477 & $\begin{array}{c}3.964 \\
(0.9490)\end{array}$ & $\begin{array}{c}4.036 \\
(0.9457)\end{array}$ & $\begin{array}{r}1.437 \\
(0.9246)\end{array}$ \\
& $(0.6834)$ & & & & 3.929 \\
Clean-FC & & & & & \\
& 0.436 & 43.181 & 12.103 & 1.467 & 5.873 \\
& $(0.6685)$ & $(0.000)$ & $(0.27820)$ & $(0.9288)$ & $(0.000)$ \\
CO2 & & & & & 6.032 \\
& 0.557 & 57.554 & 4.429 & 1.923 & $(0.000)$ \\
EffectComp & $(0.711)$ & $(0.000)$ & $(0.926)$ & $(0.973)$ & -0.549 \\
& -3.168 & 130.907 & -5.123 & & $(0.709)$
\end{tabular}




\begin{tabular}{lllccr} 
Regqulty & -1.094 & 49.808 & 34.329 & -3.972 & -0.849 \\
& $(0.137)$ & $(0.000)$ & $(0.000)$ & $(0.000)$ & $(0.802)$ \\
Efos & & & & & \\
& 0.872 & 24.690 & 15.554 & -0.365 & 3.790 \\
Electrifcant & $(0.192)$ & $(0.006)$ & $(0.113)$ & $(0.358)$ & $(0.000)$ \\
& -2.031 & 9.286 & 10.061 & 0.219 & 6.347 \\
Eneimprt & $(0.0212)$ & $(0.505)$ & $(0.435)$ & $(0.589)$ & $(0.000)$ \\
& 2.468 & 10.355 & 7.548 & 2.418 & 3.520 \\
GDPgwrth & $(0.993)$ & $(0.401)$ & $(0.673)$ & $(0.992)$ & $(0.000)$ \\
& -15.505 & 38.081 & 271.028 & -10.771 & 3.027 \\
& $(0.000)$ & $(0.000)$ & $(0.000)$ & $(0.000)$ & $(0.001)$ \\
\hline
\end{tabular}

$788 \mathrm{p}$-values in squared parentheses. The test indicates that the variable is stationary at $5 \%$.

$789 \quad$ Source:Authors' calcularion

790

791 Table.8 shows the first difference of the statitionariy of the variables.

792

793 Table 8. First difference of the statiority of the variables

\begin{tabular}{|c|c|c|c|c|c|}
\hline Variable & $\begin{array}{l}\text { LLC } \\
\text { constant }\end{array}$ & $\begin{array}{l}\text { PP-Fisher } \\
\text { Constant }\end{array}$ & $\begin{array}{l}\text { Fisher-ADF } \\
\text { constant }\end{array}$ & $\begin{array}{l}\text { IPS } \\
\text { constant }\end{array}$ & $\begin{array}{l}\text { Hadri } \\
\text { constant }\end{array}$ \\
\hline \multirow{3}{*}{ Rescons } & & 32.265 & 21.781 & -2.147 & 3.945 \\
\hline & -2.565 & 0.000 & -0.016 & -0.016 & 0.000 \\
\hline & -0.005 & & & & \\
\hline \multirow{2}{*}{ Clean-FC } & -4.646 & 37.842 & 22.814 & -2.537 & 3.534 \\
\hline & 0.000 & 0.000 & -0.012 & -0.006 & -0.002 \\
\hline \multirow[b]{2}{*}{$\mathrm{CO} 2$} & 2.932 & 414.196 & 38.348 & -4.441 & 0.008 \\
\hline & -0.998 & 0.000 & 0.000 & 0.000 & -0.497 \\
\hline \multirow{2}{*}{ EffectComp } & -1.421 & 136.994 & 52.008 & -6.009 & 0.008 \\
\hline & -0.078 & 0.000 & 0.000 & 0.000 & -0.496 \\
\hline \multirow{2}{*}{ Regqulty } & -2.923 & 335.583 & 42.156 & -4.918 & -1.261 \\
\hline & -0.001 & 0.000 & 0.000 & 0.000 & -0.896 \\
\hline \multirow{2}{*}{ Efos } & -1.799 & 308.519 & 25.619 & -2.845 & 3.785 \\
\hline & -0.036 & 0.000 & -0.004 & -0.002 & -0.001 \\
\hline \multirow{2}{*}{ Electrifcant } & -7.431 & 137.029 & 65.199 & -7.695 & 1.209 \\
\hline & 0.000 & 0.000 & 0.000 & 0.000 & -0.113 \\
\hline \multirow{2}{*}{ Eneimprt } & -3.456 & 61.665 & 27.904 & -3.091 & 4.233 \\
\hline & 0.000 & 0.000 & -0.001 & -0.001 & 0.000 \\
\hline GDPgwrth & -15.459 & 189.699 & 281.85 & -10.919 & 4.694 \\
\hline
\end{tabular}


794 Source:Authors'calculation p-values in squared parentheses. The test indicates that the variable

795 is stationary at $5 \%$.

796 Table 9. Second generation Unit root tests

\begin{tabular}{llc}
\hline Variables & Bai and NG & Pesaran's CADF test \\
\hline \multirow{2}{*}{ rescons } & 5.721 & -5.781 \\
Clean-FC & 0 & -0.01 \\
$\mathrm{CO}_{2}$ & -0.416 & -604322 \\
& -0.677 & -0.01 \\
EffectComp & 2.512 & -0.073 \\
& -0.12 & -0.1 \\
Regqulty & -1.553 & 0.003 \\
& -0.12 & -0.1 \\
Efos & -1.694 & -2.040 \\
Electrifcant & -0.090 & -0.1 \\
& & -6.157 \\
Eneimprt & -1.300 & -0.01 \\
GDPgwrth & -1.194 & -2.710 \\
& 2.160 & -0.01 \\
& -0.308 & -22173 \\
\hline
\end{tabular}

797

798

799

800

801

802

803

804

805

806

807

Source:Authors'compilation: p-values in squared parentheses.

The test indicates that the variable is stationary at 5\%. From the analysis in table 9 . all most of the varibales are nonstationary, using the Bai and $\mathrm{Ng}(2001,2004)$ to test cross sectional he augments dependence. On the other hand, all the varibales became stationary using the Pesaran's CADF test, the standard Dickey-Fuller or Augmented Dickey-Fuller regressions which allows for the cross section of average lagged levels and first difference of the series. Thus, all the varibles are stationary without taking their $1(\mathrm{I})$.Hence the null hypothesis is rejected that there is unit root in the panel. Now comparing the results of the Peasaran's CADF's test in the second generation in table 5 to the IPS in the frist generation, showes the varibales in Table 9 are nonstationary and 
808 only became stationary after their I(1). However, with the Peasaran test in the second generation, 809 the varibles assume statioanrity without taking their I(1).

810

811
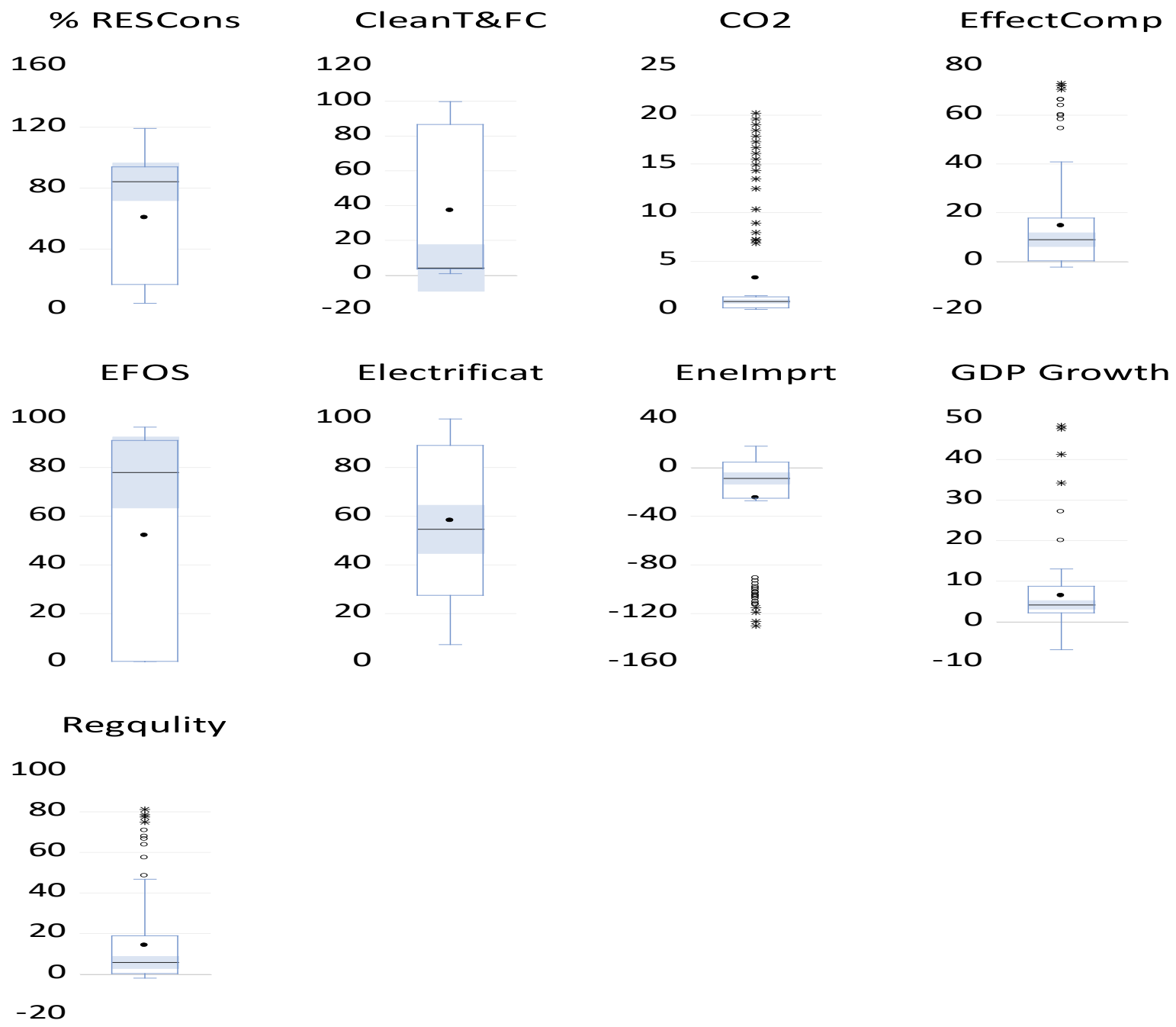

813

Figure 3. Boxpot of the underlying variables

814 From gigure 3 the Boxplot maximum value for_rescons is about $85 \%$ and the median value 40.

815 On the other hand, the variable on Clean T and FC has a low maximum value of 19 and the 816 minimum of nearly [-20].This explains how insiginficant the variable is in the study countries.

817 Electricity from fossil fuels sources has the higest Boxplot maximum value of nearly 100, followed 818 by electricifaction in the study countries. Africa generates about $81 \%$ of its electricity from fossil 
819 fuels sources(Alemzero et al., 2020). $\mathrm{CO}_{2}$ has the least Boxplot value of less than 1.That explains 820 the negiglible levels of $\mathrm{CO}_{2}$ emission among gthr study countris, other than south Africa and Egypt.

821

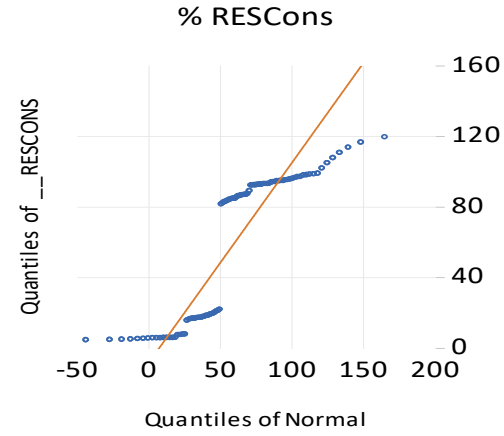

EffectComp

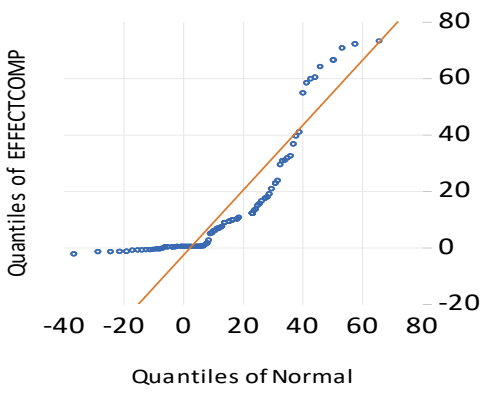

Quantiles of Normal

Enelmprt

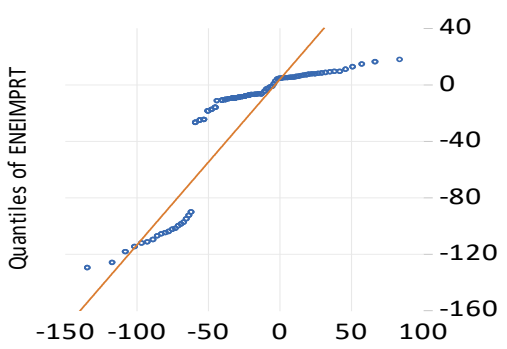

Quantiles of Normal
CleanT\&FC

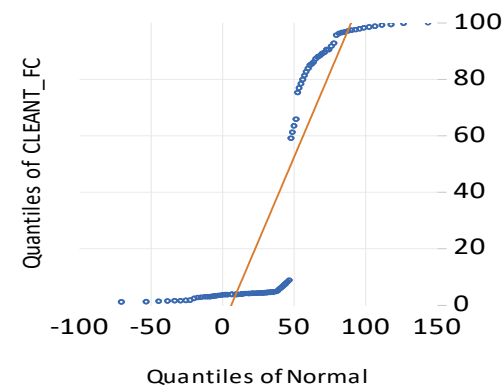

EFOS

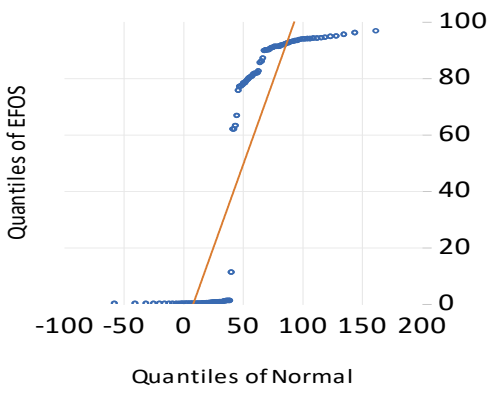

GDP Growth

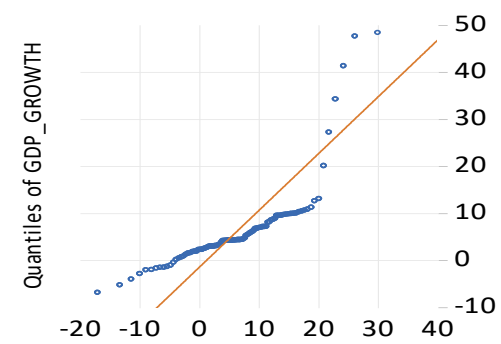

Quantiles of Normal
$\mathrm{CO} 2$

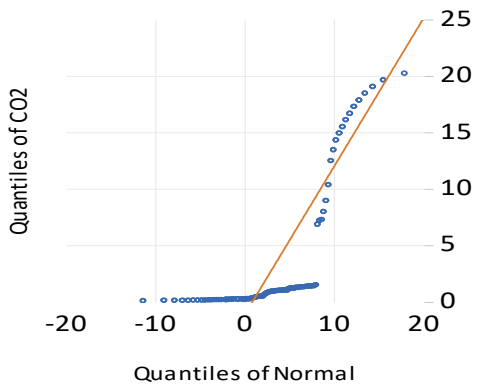

Electrificat

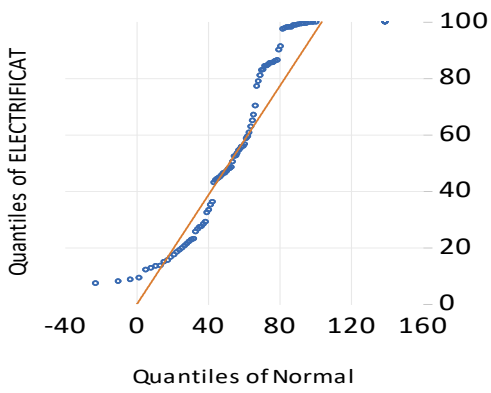

Regqulity

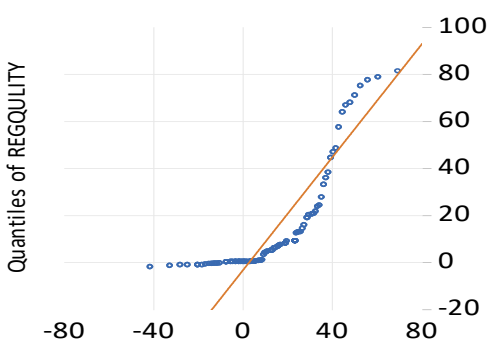

Quantiles of Normal
822

823

824

825 Figure.4 shows the quantile dispersion of the underlying variables. From the descriptive statistics,

826 Electrification has the highest mean score, suggesting that most countries are fully electrified.

827 EFOS has the second highest mean value, implying the countries generate a lot of their electricity

828 from fossil fuel sources. Another striking mean value is ENEIMPRT, which is negative, showing

Figure. 4 Quantile Dispersion of the underlying variables 
830 study countries don't emit so much $\mathrm{CO}_{2}$, except South Africa. The correlation matrix explains the

831 relationship between the variables, which has the highest correlational value and sees the variables'

832 relationships. The interaction of CLEANT_FC and _RESCONS has the highest correlation

833 among them. However, the relationship is a negative one of[-0.979], whichs indicates as one

834 varibales increases the other variable decreases. That is followed by the interaction of

835 ELECTRIFICAT and_RESCONS, which as the correlation value of [-0.933]. The correlation is

836 a negative one as well. The variables that have the weakest correlation is the interaction of

837 REGQULITY and ENEIMPRT,also has a negative correlation[-0.006]. Electrification has a

838 strong correlation close to 1 , which is preferable. Also, access to clean fuels and technologies has

839 a strong correlation to the dependent Variable too. $\mathrm{CO}_{2}$, as well as ENEIMPRT, has the least

840 correlation values. The relationship, will give insight as to which Variable needs further

841 investigation. Linear regression correlation does not necessarily have to have a high correlation;

842 thus, these results show a high sense of reliability, making inferences from the table 10.

843 Table.10 Westerlund error correction

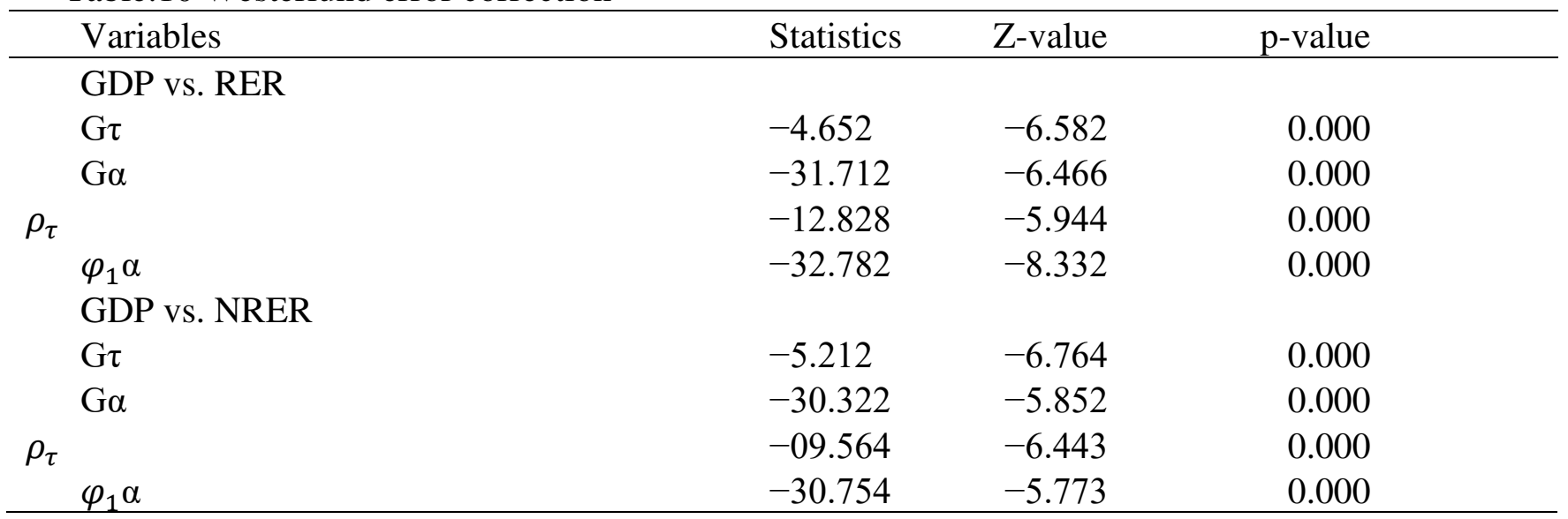

844

845 The Westerlund error correction is shown in Table. 10. A range of 4.665 to -32.712 defines the

846 GDP vs RER parameters. On the other hand, a range of -5.212 to -30.754 defines the GDP vs

847 NRER values. 


\begin{tabular}{cllrrrrrrrr}
\hline$\tau$ & $\alpha_{\tau}$ & \multicolumn{1}{l}{$\rho_{\tau}$} & \multicolumn{1}{c}{$\beta_{C O_{2}}(\tau) \beta_{G D P}(\tau)$} & $\beta_{K}(\tau)$ & $\varphi_{1}(\tau)$ & $\omega_{0}(\tau)$ & $\lambda_{0}(\tau)$ & $\lambda_{1}(\tau)$ & $\omega_{1}(\tau)$ \\
\hline $0.691^{* * *}$ & $-0.116^{* * *}$ & -0.311 & 0 & $0.145^{* *}$ & $0.492^{* * *}$ & $0.168^{* * *}$ & -0.041 & 0.045 & $-0.395^{* * *}$ & $0.344^{* * *}$ \\
-0.16 & -0.02 & -0.2 & -0 & -0.06 & -0.1 & -0.07 & -0.03 & -0.028 & -0.08 & -0.088 \\
\hline
\end{tabular}

Results indicating the rejection of the null hypothesis. Whereas, the alternative hypothesis

851 parameter for long-term quantile integration implies the rejection of $\beta$ GDP in case of emerging

852 African economies. A negative relationship between GDP growth and greenhouse gasses'

853 emission is evident from the results shown in Table. 11 for the African countries under

854 consideration.

\section{Conclusion and Policy Implication}

856 It analyzed these factors to see how they impact deploying renewables by employing panel data

857 using the pooled ordinary least squared(OLS) at frim level analysis. After the analysis, we proved

858 that access to clean fuels and technologies for cooking needs the study countries to deploy

859 renewables as most Africans cook with polluting fuels having detrimental health implications. The

860 analyses further revealed that these countries generate a chunk of their electricity from fossil fuel

861 sources, making it imperative to jettison fossil fuels and embrace renewables cheaper and

862 environmentally friendly. This study researched how to scale up renewables in Africa's five most

863 populous countries 2001-2019 using the world bank development indicators (WDI) and the world

864 bank governance indicators (WGI). The explanatory variables employed in the study are energy

865 imports, $\mathrm{CO}_{2}$, Quality of regulatory environment, access to electricity nationally, access to clean

866 fuels and technologies for cooking, the effectiveness of compliance, GDP growth rate, and 867 electricity generation from fossil fuel sources and renewable consumption of total energy 868 consumption as the dependent Variable. Furthermore, the lack of electrification is important to 869 developing renewal energy sources in the study countries while deploying renewables will bridge 
870 the access gap. Countries have the practical and theoretic potential for all the renewable energies

871 required to guarantee sustainable consumption. The financial policy de-risking instruments to

872 crowd in private capital since the renewables sector is perceived as a high-risk area.

873 The paper provides an empirical analysis of renewable energy deployment in the five populous

874 countries with an econometric approach.We discovered that all the explanatory variables except

875 EFFECTCOMP were significant in determining renewables' scaling up in Africa. Thus, if the study

876 countries want to achieve universal access to electricity in their countries, renewables are the best

877 bet. Electrification has a direct correlation to renewable energy generation in the analysis and also

878 perfectly significant. For instance, the DRC has the least electrification rate among the "Big Five";

879 thus, renewables for that matter off-grid solutions will be the panacea to creating access in the

880 DRC and Africa in generation.

881 Access to clean cooking fuels and technologies is equally significant but has an inverse

882 relationship to the dependent Variable. Most people in the study countries except South Africa and

883 Egypt cook with Biomass hurting their health and sometimes deadly. Thus renewables will be the

884 solution here.

885 The analysis also confirmed that most of the study countries generate the bulk of their electricity

886 from fossil fuels source, which is not sustainable. The correlation to the dependent Variable is

887 negative, which is appropriate, implying fossil electricity generation increases, renewables

888 consumption on the final consumption decreases. Given this, it is recommended that policies be

889 formulated to speed up renewables deployment.

890 Furthermore, the Quality of the country's regulatory environment is very important in scaling

891 renewables in Africa. The Variable is significant. The fact is, Africa cannot transition to 892 renewables without the right policy mix. 
894 The authors declare that they have no known competing financial interests or personal 895 relationships that seem to affect the work reported in this article. We declare that we have no 896 human participants, human data or human tissues.

\section{Funding}

898 Not Applicable

899 Consent for Publication

900 Not Applicable

901 Author Contribution

902 Dinh van Tien: Conceptualization, Data curation, Methodology, Writing - original draft. Thai 903 Van Ha : Data curation, Visualization. Tran Duc Thuan: review \& editing. Thai Thi Kim Oanh 904 Writing - review \& editing and software. Nguyen Phan Thu Hang: Visualization, supervision, 905 editing, Pham Thi Lan Phuong: Methodology, Data curation, Visualization, Funding This 906 research did not receive any specific funding from public, commercial or non profit sector funding 907 agencies.

\section{Competing interest statement}

909 We declare that there is no conflict of interest

910 Availability of data and materials

911 The data that support the findings of this study are attached

912 Reference

913 AfDB. (2020). African Economic Outlook 2020 Amid O VID-19 SUPPLEMENT. 914 https://www.afdb.org/sites/default/files/documents/publications/afdb20-

915 04_aeo_supplement_full_report_for_web_0705.pdf\#page=60

916 Akintande, O. J., Olubusoye, O. E., Adenikinju, A. F., \& Olanrewaju, B. T. (2020). Modeling the 
determinants of renewable energy consumption: Evidence from the five most populous nations in Africa. Energy, 206, 117992. https://doi.org/10.1016/j.energy.2020.117992

Alemzero, D. A., Sun, H., Mohsin, M., Iqbal, N., \& Nadeem, M. (2020). Assessing energy security in Africa based on multi-dimensional approach of principal composite analysis.

Aliyu, A. K., Modu, B., \& Tan, C. W. (2018). A review of renewable energy development in Africa: A focus in South Africa, Egypt and Nigeria. Renewable and Sustainable Energy Reviews, 81(February 2016), 2502-2518. https://doi.org/10.1016/j.rser.2017.06.055

Bank African Development. (2019). African Economic Outlook 2019: Macroeconomic performance and prospects Jobs, growth, and firm dynamism Integration; Integration for Africa's economic prosperity.https://www.afdb.org/fileadmin/uploads/afdb/Documents/Publications/2019AEO /AEO_2019-EN.pdf

Beyene, G. E., Kumie, A., Edwards, R., \& Troncoso, K. (2018.). Opportunities for transition to clean household energy in Ethiopia.

Bohlmann, J. A., \& Inglesi-lotz, R. (2018). Analysing the South African residential sector ' s energy pro fi le. Renewable and Sustainable Energy Reviews, 96(December 2017), 240-252. https://doi.org/10.1016/j.rser.2018.07.052

Bloomberg NEF, C. C. (2020). Sub-Saharan Africa Market Outlook 2020.Available at: http://global-climatescope.org/assets/data/docs/updates/2020-02-06-sub-saharan-africa-marketoutlook-2020.pdf

Castellano, A., Kendall, A., Nikomarov, M., \& Swemmer, T. (2015). Powering Africa. February.

Connecting the dots, why $2 \%$ of RE in Africa C. (2020). Available at: https://www.res4africa.org/2020/07/08/connecting-the-dots-why-only-2-of-global-re-inafrica/1.

da Silva, P. P., Cerqueira, P. A., \& Ogbe, W. (2018). Determinants of renewable energy growth in Sub-Saharan Africa: Evidence from panel ARDL. Energy, 156, 45-54. https://doi.org/10.1016/j.energy.2018.05.068

Dagnachew, A. G., Hof, A. F., Lucas, P. L., \& Vuuren, D. P. Van. (2019). Scenario analysis for promoting clean cooking in Sub-Saharan Africa: costs and benefits. Energy, 116641. https://doi.org/10.1016/j.energy.2019.116641

Dorothal, M. (2019). Ethiopia Solar Report. Solar Plaza International, July, 18. https://sunconnect-news.org/fileadmin/DATEIEN/Dateien/New/White_Paper__Ethiopia_Solar_Report_2019.pdf

Edkins, M., Marquard, a., \& Winkler, H. (2010). South Africa's renewable energy policy roadmaps. Energy, June, 1-28. 
Egyptian Electricity Holding Company. (2018). Egyptian Electricity Holding Company Annual Report 2017/2018. Eehc, 1-85. https://doi.org/10.1017/CBO9781107415324.004

Elsayed, A. M., Mishref, M. M., \& Farrag, S. M. (2018). Distribution system performance enhancement (Egyptian distribution system real case study). International Transactions on Electrical Energy Systems, 28(6), 1-24. https://doi.org/10.1002/etep.2545

Ethiopian. Governmnet. (2018.). Africa Energy Market Place (AEMP).Available at: https://www.afdb.org/fileadmin/uploads/afdb/Documents/GenericDocuments/AEMP/AEMP_Concept_Note_v.15.pdf

For, V., \& Efficiencycompetitiveness, I. (n.d.). NCPC-SA: South Africa.Available at: http://ncpc.co.za/

García-Álvarez, M. T., Cabeza-García, L., \& Soares, I. (2017). Analysis of the promotion of onshore wind energy in the EU: Feed-in tariff or renewable portfolio standard? Renewable Energy, 111, 256-264. https://doi.org/10.1016/j.renene.2017.03.067

Godinho, C., \& Eberhard, A. (2019). Learning from Power Sector Reform : The Case of Kenya. World Bank Policy Research Working Paper, 8819.

Government of Nigerian. (2018.). Africa Energy Market Place (AEMP). Government of Nigeria (2018). Africa Energy Market Place (AEMP).Available at:1 https://africa-energyportal.org/country/Nigeria

Guta, D. D. (2020). Determinants of household use of energy-efficient and renewable energy technologies in rural Ethiopia. Technology in Society, 61, 101249. https://doi.org/10.1016/j.techsoc.2020.101249

Hamed, M. M., \& El Mahgary, Y. (2004). Outline of a national strategy for cleaner production: The case of Egypt. Journal of Cleaner Production, 12(4), 327-336. https://doi.org/10.1016/S0959-6526(03)00037-4

Hepburn, C., O’Callaghan, B., Stern, N., Stiglitz, J., \& Zenghelis, D. (2020). Will COVID-19 fiscal recovery packages accelerate or retard progress on climate change? Oxford Review of Economic Policy, 36(Supplement_1), S359-S381. https://doi.org/10.1093/oxrep/graa015

Hossain, A., Getaneh, A., Gebrehiwot, K., \& Ringler, C. (2014). Ethiopian Universal Electrification Development Strategies.

Hurlin, C., \& Mignon, V. (2007). Second Generation Panel Unit Root Tests To cite this version : HAL Id: halshs-00159842 Second Generation Panel Unit Root Tests. 1-25. https://halshs.archives-ouvertes.fr/halshs-00159842

IEA. (2019). Africa Energy Outlook 2019 Africa Energy Outlook 2019.Available at https://www.iea.org/reports/africa-energy-outlook-2019

Increasing Access To Electricity in The Democratic Republic of 
Congo.(2020.).Available:http://documents1.worldbank.org/curated/en/74372158683681020 3/pdf/Increasing-Access-to-Electricity-in-the-Democratic-Republic-of-CongoOpportunities-and-Challenges.pdf

IRENA.(2019). Renewable Power Generation Costs in . Available at:https://www.irena.org/publications/2020/Jun/Renewable-Power-Costs-in-2019

IRENA. (2017). Renewable energy auctions. In Renewable Energy Auctions : Analysing 2016 (Vol. 1, Issue 14). https://www.irena.org//media/Files/IRENA/Agency/Publication/2017/Jun/IRENA_Renewable_Energy_Auctions_ 2017.pdf

IRENA. (2019). Scaling Up Renewable Energy Development in Africa: Impact of IRENA's Engagement. January, 1-4. https://www.irena.org//media/Files/IRENA/Agency/Publication/2019/Jan/IRENA_Africa_impact_2019.pdf?la=en \&hash=6B16ABE754FF6F843601E1E362F5D6B730ADF7A2

Jewitt, S., Atagher, P., \& Clifford, M. (2020). Energy Research \& Social Science “ We cannot stop cooking ": Stove stacking, seasonality and the risky practices of household cookstove transitions in Nigeria. Energy Research \& Social Science, 61(May 2019), 101340. https://doi.org/10.1016/j.erss.2019.101340

Mentis, D., Hermann, S., Howells, M., Welsch, M., \& Siyal, S. H. (2015). Assessing the technical wind energy potential in Africa a GIS-based approach. Renewable Energy, 83, 110-125. https://doi.org/10.1016/j.renene.2015.03.072

Mondal, M. A. H., Ringler, C., Al-Riffai, P., Eldidi, H., Breisinger, C., \& Wiebelt, M. (2019). Long-term optimization of Egypt's power sector: Policy implications. Energy, 166, 10631073. https://doi.org/10.1016/j.energy.2018.10.158

Narula, K. (2019). Energy security and sustainability. Lecture Notes in Energy, 68(October 2018), 3-22. https://doi.org/10.1007/978-981-13-1589-3_1

Nassar, I. A., \& Abdella, M. M. (2019). Effects of Increasing Wind and Solar Power Energy on the Voltage Stability and Losses of the Egyptian Power System. 2018 20th International Middle East Power Systems Conference, MEPCON 2018 - Proceedings, 887-893. https://doi.org/10.1109/MEPCON.2018.8635114

Olanrewaju, B. T., Olubusoye, O. E., Adenikinju, A., \& Akintande, O. J. (2019). A panel data analysis of renewable energy consumption in Africa. Renewable Energy, 140, 668-679. https://doi.org/10.1016/j.renene.2019.02.061

Roche, M., Ude, N., \& Donald-Ofoegbu, I. (2017). True Cost of Electricity: Comparison of Costs of Electricity Generation in Nigeria. Nigerian Economic Summit Group and Heinrich Böll Stiftung Nigeria, June, 1-34. https://ng.boell.org/sites/default/files/true_cost_of_power_technical_report_final.pdf

REN21, R. E. N. (2020). Renewables 2020 global status report 2020.Available at: 
RES4(2020) SCALING Up renewable Africa's Power. The need for de-risking investments and the renewafricAhttps://culture.go.th/mculture_th/download/king9/Glossary_about_HM_King_ Bhumibol_Adulyadej's_Funeral.pdf

Sakr, D., \& Abo Sena, A. (2017). Cleaner production status in the Middle East and North Africa region with special focus on Egypt. Journal of Cleaner Production, 141, 1074-1086. https://doi.org/10.1016/j.jclepro.2016.09.160

SEforALL Sustainable Energy for All. (2020). The recover better with sustainable energy guide for african countries. United Nations Publications, 53(9), 21. https://doi.org/10.1017/CBO9781107415324.004

Selvakkumaran, S., \& Silveira, S. (2018). Exploring synergies between the intended nationally determined contributions and electrification goals of Ethiopia, Kenya and the Democratic Republic of Congo ( DRC ). Climate and Development, 0(0), 1-17. https://doi.org/10.1080/17565529.2018.1442800

Smillie, I. (2013). The world bank. Stakeholders: Government-NGO Partnerships for International Development, 278-287. https://doi.org/10.4324/9781315071299-37

Sun, H., Khan, A. R., Bashir, A., Alemzero, D. A., Abbas, Q., \& Abudu, H. (2020). Energy insecurity, pollution mitigation, and renewable energy integration: prospective of wind energy in Ghana. Environmental Science and Pollution Research, 27(30), 38259-38275.

Ugwoke, B., Gershon, O., Becchio, C., Corgnati, S. P., \& Leone, P. (2020). A review of Nigerian energy access studies: The story told so far. Renewable and Sustainable Energy Reviews, 120(June 2019), 109646. https://doi.org/10.1016/j.rser.2019.109646

Uken, E. (2006). The electricity supply industry in the Democratic Republic of the Congo. 17(3), 21-28.Available

at: http://www.erc.uct.ac.za/sites/default/files/image_tool/images/119/jesa/17-3jesalukamba.pdf

US EIA. (2018). Country Analysis Brief: Egypt. Country Analysis Brief: Iran, 18, 1-7. https://www.eia.gov/beta/international/analysis_includes/countries_long/United_Arab_Emir ates/uae.pdf

Wall, R. F. (1960). An Atlas of Africa. In International Affairs (Vol. 36, Issue 3). https://doi.org/10.2307/2610110

World Bank G. (2020.) Cooking with electrcity avaialble at: https://openknowledge.worldbank.org/handle/10986/34566

World Bank, G. (2011). Linking Up : Public-Private Partnerships in Power Transmission in Africa Linking Up: Public-Private Partnerships in Power Transmission in Africa.Available at: 
1060 https://openknowledge.worldbank.org/bitstream/handle/10986/32335/9781464814426.pdf?s 1061 equence $=10 \&$ is Allowed $=\mathrm{y}$

1062

1063

1064

1065

1066

1067

1068

1069

1070

1071

1072

1073

1074

1075

1076 
Figures

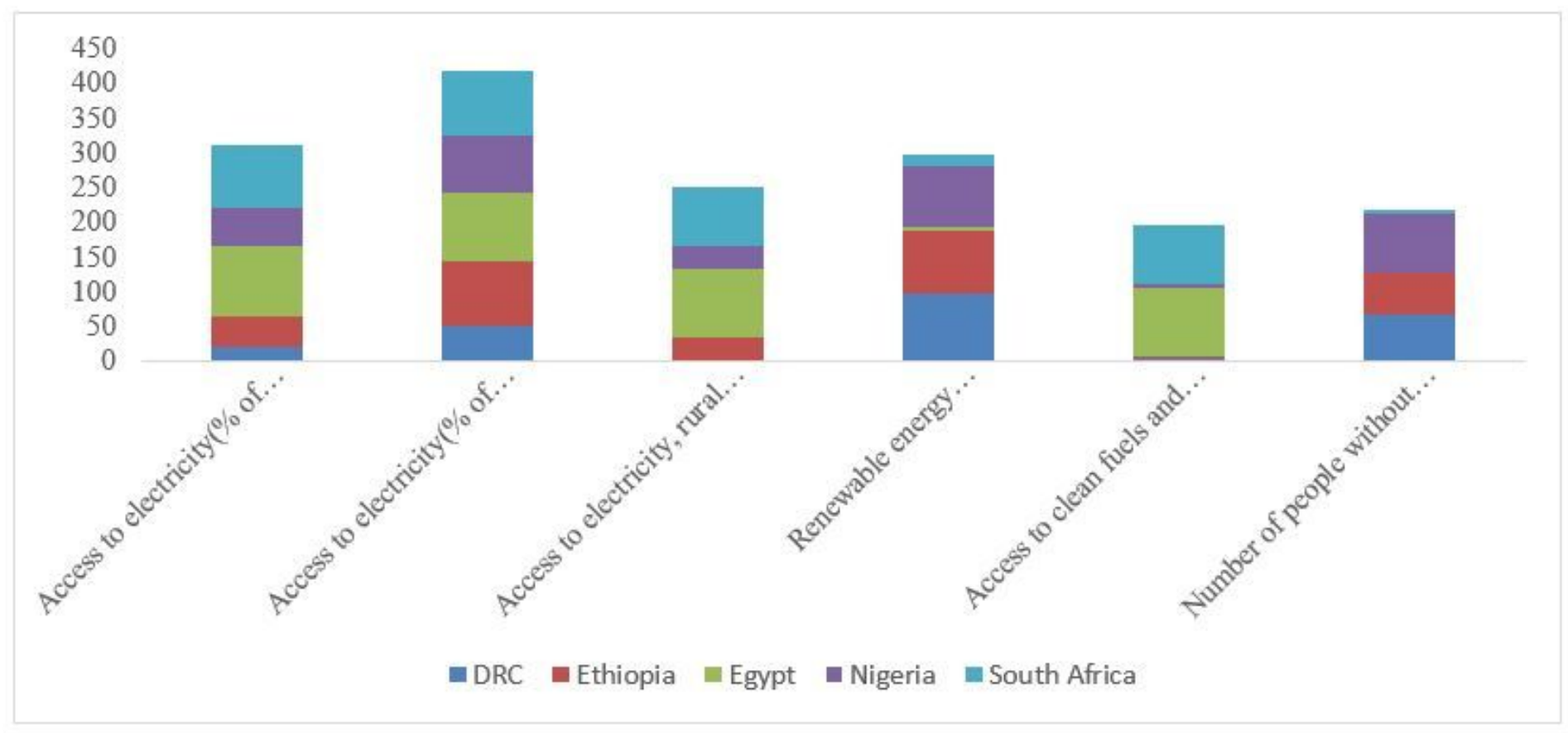

Figure 1

Electricity access map in Africa

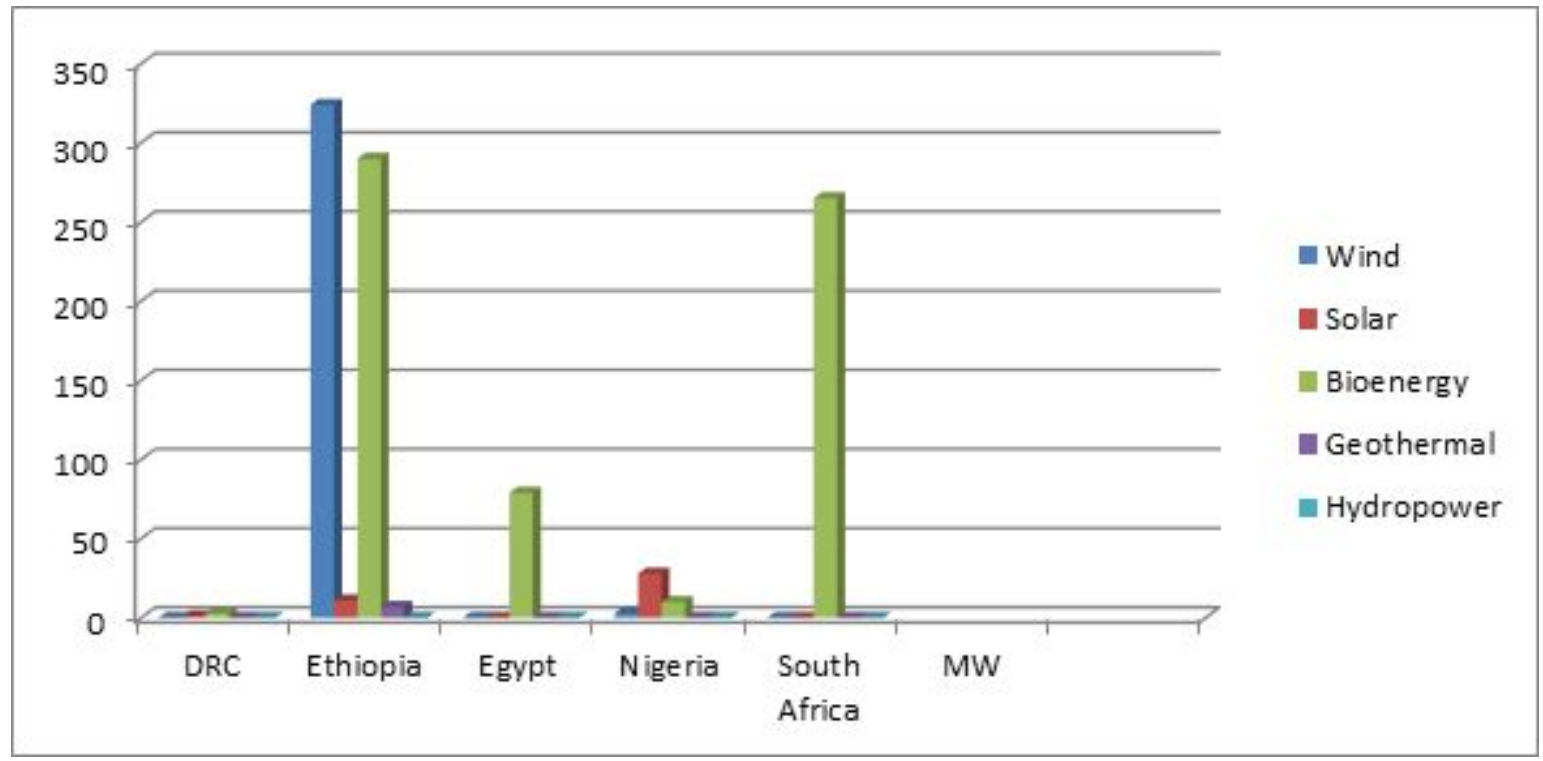

Figure 2

Electricity access map in Africa 

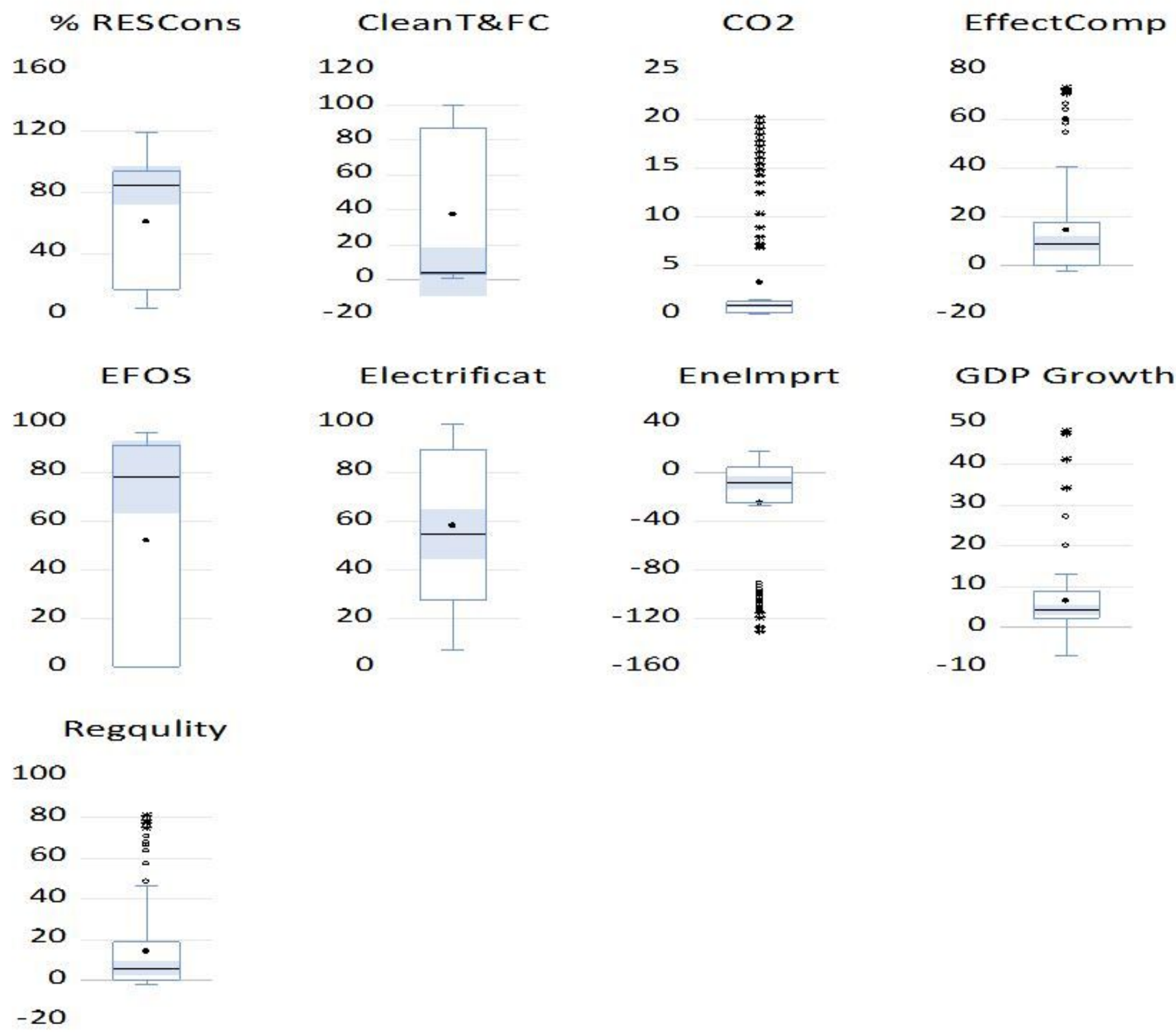

Figure 3

Boxpot of the underlying variables 


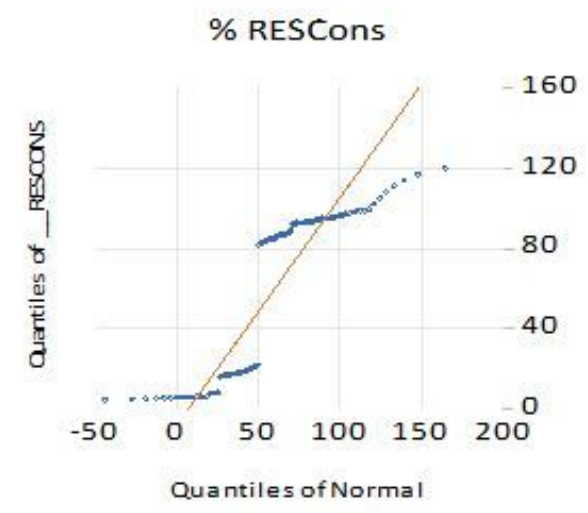

EffectComp

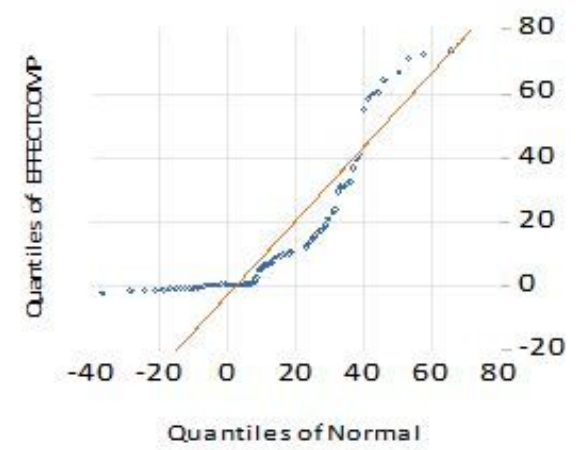

Enelmprt

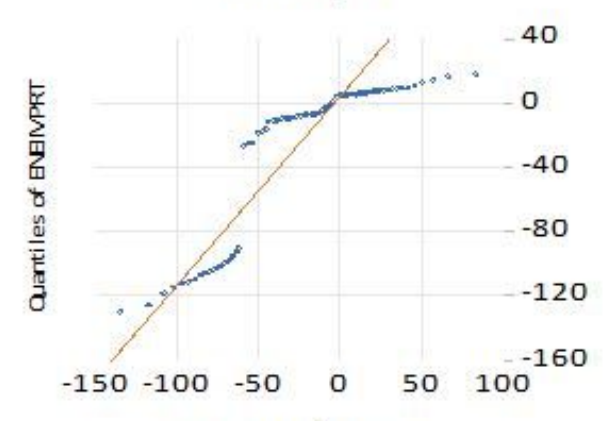

Quantiles of Normal

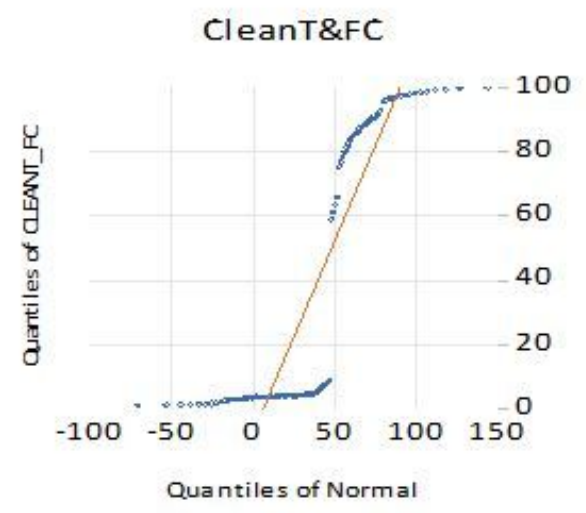

EFOS

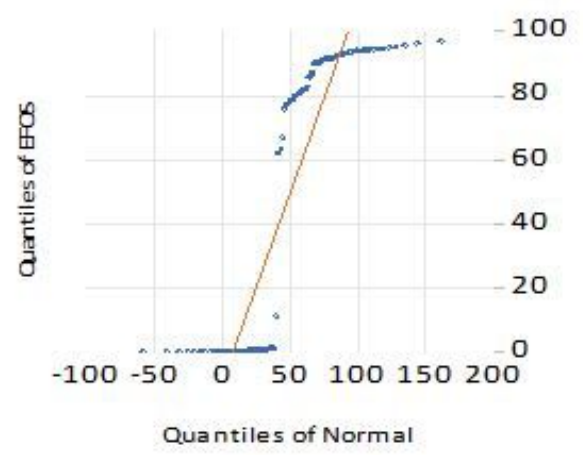

GDP Growth

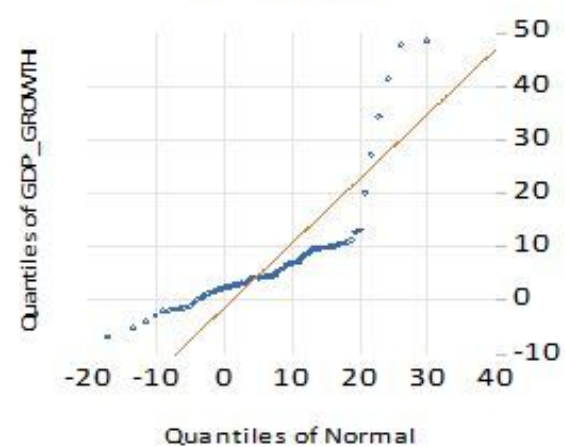

$\mathrm{CO} 2$

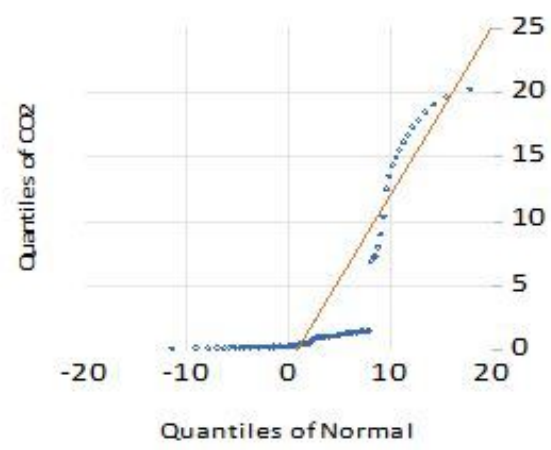

Electrificat

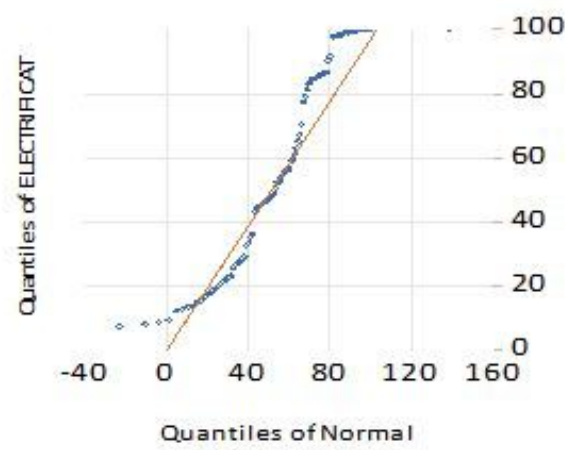

Regqulity

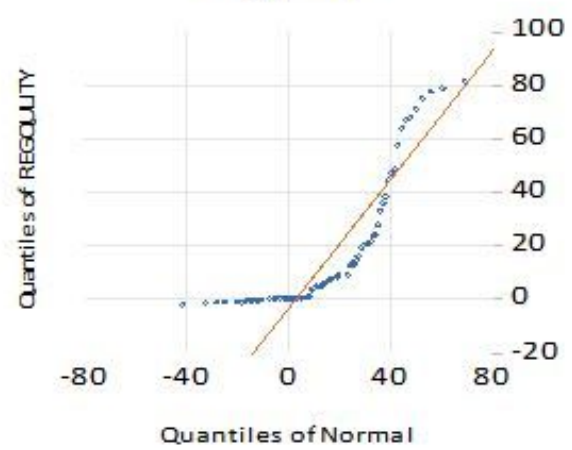

Figure 4

Quantile Dispersion of the underlying variables 